\title{
Does Maturity Matter? The Case of Treasury Futures Volume*
}

\author{
Doina Chichernea ${ }^{\dagger}$ \\ University of Toledo \\ Kershen Huang ${ }^{\S}$ \\ Bentley University \\ Christopher P. Crandall ${ }^{\ddagger}$ \\ University of Toledo Physicians \\ Alex Petkevich \\ University of Toledo
}

May 22, 2017

\begin{abstract}
We argue that Treasury futures volume is generated by investors' differences in beliefs about future economic activity and therefore contains information about the future economy and financial markets. However, short- and long-term volumes contain different information, consistent with the idea that agents with different levels of risk aversion dominate these different segments of the market. A relatively higher volume in short-term (long-term) Treasury futures is counter-cyclical (pro-cyclical), thus preceding worse (better) economic and financial conditions. We construct a single factor from trading volumes with different maturities that forecasts the performance of Treasuries, corporate debt, and equity, as well as macroeconomic conditions.
\end{abstract}

JEL Classification: G11, G12, G13

Keywords: Financial markets, macroeconomic conditions, Treasury futures, volume

${ }^{*}$ We thank Elmira Shekari Namin, David Simon, Jahangir Sultan, and the seminar participants at Oregon State University, Peking University (HSBC School), the University of Denver, and the 2016 Boston Area Finance Symposium in Lowell, MA for insightful comments and suggestions. Any errors or omissions are the authors' alone.

${ }^{\dagger}$ Neff Department of Finance, College of Business and Innovation, University of Toledo, Toledo, OH 43606. E-Mail: doina.chichernea@utoledo.edu

${ }^{\ddagger}$ University of Toledo Physicians, LLC., Toledo, OH $43606 . \quad$ E-Mail: christopher.crandall@rockets.utoledo.edu

${ }^{\S}$ McCallum School of Business, Bentley University, Waltham, MA 02452. E-Mail: khuang@bentley.edu

INeff Department of Finance, College of Business and Innovation, University of Toledo, Toledo, OH 43606. E-Mail: alexey.petkevich@utoledo.edu 


\section{Introduction}

Treasury futures trading volume is an important economic indicator that contains information about investors' beliefs (Xiong and Yan, 2010) and, therefore, can predict asset prices and macroeconomic conditions. We extend this stream of literature by arguing that the Treasury futures markets with different maturities attract agents with different preferences and, therefore, volumes in these different segments have different implications for future financial and economic conditions. We document that the volume of relatively short-term (long-term) Treasury futures is counter-cyclical (pro-cyclical), thus preceding worse (better) performances of debt and equity capital markets and deteriorating (improving) economic conditions. Further, we find a single factor combined of futures trading volumes that (i) explains yields and excess returns on Treasury securities, (ii) predicts the performances of corporate debt and equity, and (ii) forecasts macroeconomic conditions, including GDP, consumption, industrial production, and unemployment growth. ${ }^{1}$

Our research is motivated by the information content of the trading activity in the Treasury futures markets. Trading volumes, in particular, communicate market participants incentives to transact. To give a few examples, a bank that wishes to hedge its interest rate risk exposure from an underlying asset portfolio would short futures, an insurance company that expects to collect premiums and use the proceeds to purchase securities would long futures, and speculators who anticipate movements in rates can go either long or short futures. Despite the direction of the trades, these examples show that market participants facilitate transactions through differences in information recognition and processing (Working, 1953; Grossman, 1975, 1977) and incentives to transfer risk (Hicks, 1946; Keynes, 1930). Impor-

\footnotetext{
${ }^{1}$ As opposed to the usual textbook terminologies that use one-year or several months as the cut-off (e.g., Morgenson and Harvey, 2002), we define the terms "short-term interest rates" and "long-term interest rates" relatively as the pricing of two-year, five-year, ten-year, and thirty-year Treasury securities. We do not include futures contracts on Treasury bills and other money market rates in this study, but only Treasury futures that are traded on the Chicago Board of Trade (CBOT of CME Group).
} 
tantly, as differences in beliefs among market participants become larger, they have stronger incentives to take on positions against one another and collectively produce higher trading volumes as new information arrives. The basis of our motivation is thus that higher trading volumes are indicative of higher dispersion in the beliefs of market participants (Xiong and Yan, 2010). ${ }^{2}$

Building on this foundation, we consider the economic differences between the trading volumes of relatively short-term and long-term Treasury futures. We argue that when investors transact more heavily in a certain segment of the market (e.g., a stronger focus on short-term rates), they aggregately convey information regarding their risk aversion and investment preferences. ${ }^{3}$ While long-term interest rates are, to some extent, averages of sequential short-term rates, short-term and long-term spot rates are not identically determined. Due to the stickiness of prices, short-term rates are less likely to reflect economic fundamentals, but rather fluctuations in the demand and supply of money (Keynes, 1930, 1936): Demand is tied to the trade-off between opportunity costs and liquidity benefits of holding money; supply is determined by the central banking system. For extended horizons, stickiness dissipates and prices become flexible, allowing long-term rates to more heavily reflect fundamentals such as market expectations of economic activity and productivity (Hong and Yogo, 2012, argue similarly for overall open interest). For instance, compared to a change in real output, an alteration in money supply by itself would be less relevant for variations in long-term interest rates (Patinkin, 1987). ${ }^{4}$

\footnotetext{
${ }^{2}$ For further readings on the relation between differences in beliefs and asset prices, see Ehling et al. (2017) and Hong et al. (2017). The connection between movements of interest rates and activities in futures markets is also illustrated in Hamilton (2009) and Jegadeesh and Pennacchi (1996).

${ }^{3}$ Existing literature suggests that volumes signal investors investment preferences, such as in the shortterm or long-term segments of the market (Cornell, 1981; Grammatikos and Saunders, 1986; Tauchen and Pitts, 1983). For additional evidence on how investor preferences can be revealed through investment behaviors and portfolio holdings, see Bennett et al. (2003) and Falkenstein (1996).

${ }^{4}$ According to data provided by the Organisation for Economic Co-operation and Development (OECD) during the period of 1970-2010, the idea of money neutrality is supported in the long run (Krugman and Wells, 2012).
} 
In sum, a higher volume in relatively short-term (long-term) futures is more (less) likely driven by reactions of market participants to uncertainties in the economic environment and reflects the lower (higher) level of aggregate risk aversion of the investors in those respective market segments (Beber et al., 2009; Guiso et al., 2015). Since the trading volumes of short-term and long-term Treasury futures contain information about overall risk aversion and investor preferences, and therefore the corresponding interest rates, they should also have the capacity to forecast asset prices (Cochrane and Piazzesi, 2005) and real output fluctuations (Carlton, 1984; Martell and Wolf, 1987). We are essentially asking the following research question: Can market activities in short-term and long-term interest rate futures contracts predict asset prices and macroeconomic conditions? Based on our interpretations of volume, we hypothesize so.

Our empirical approach to answering this question has three steps. First, we provide validation that futures trading volumes are indeed legitimate proxies for market participants' beliefs and attitude towards risk at the aggregate level. Second, we show that futures volumes predict the prices of debt and equity capital and macroeconomic variables. Third, we use Treasury trading volumes to derive a common factor that bears forecasting power across capital markets and macroeconomic conditions. ${ }^{5}$

In order to validate the use of futures trading volumes as empirical proxies for heterogeneous beliefs and risk aversion (i.e., the first step), we test Buraschi and Whelan's (2016) theoretical predictions regarding the relation between the level of disagreement (volume) and the dynamics of interest rates in different regimes of aggregate level risk aversion (i.e. short- or long-term treasury futures markets). Lower risk aversion encourages speculation and introduces higher expected returns through the associated higher endogenous quantity of risk. Based on the substitution and wealth implications derived from intertemporal con-

\footnotetext{
${ }^{5}$ This exercise is analogous to the restricted, one-factor estimation of Treasury bond risk premia in Cochrane and Piazzesi (2005).
} 
sumption choices, this leads to a lower present value of future consumption, making it less expensive and therefore more attractive relative to current consumption. As the demand for savings increases, short-term rates drop (i.e., the substitution effect from less expensive future consumption dominates). A higher level of risk aversion, oppositely, increases hedging demand and raises the drift of planned consumption today (i.e., the wealth effect dominates through the traditional channel of Lucas, 1978).

We test the following three implicatons from this model: 1) short-term (long-term) volume would be associated with lower (higher) interest rates, with a stronger effect on shortterm rates; 2) The stronger effect of risk aversion on short rates relative to long-term rates also implies that the slope of the Treasury yield curve would be inversely related to risk aversion; 3) low risk aversion levels alongside differences in beliefs should have the power to predict positive excess bond returns. ${ }^{6}$ Using data on two-, five-, ten-, and thirty-year Treasury futures over the sample period of 1995 to 2014, we find what we expect. Specifically, the trading volumes of short-term (long-term) interest rate futures are associated with lower (higher) bond yields, larger (smaller) term spreads, and higher (lower) Treasury excess returns.

Next, we study the predicting power of Treasury futures volume in the corporate debt and equity capital markets, as well as for various macroeconomic variables (i.e., the second step identified above). We find statistically and economically significant support for our hypothesis: Our time-series regressions indicate that the futures volume of shorter (longer) maturity Treasuries precedes worse (better) performance of the equity markets and is counter-cyclical (pro-cyclical) in predicting macroeconomic conditions. For corporate debt capital, the effect is only evident in junk bonds, where economic uncertainty is most relevant.

Finally, we construct a single, common factor that has predicting power across capital

\footnotetext{
${ }^{6}$ Obtaining positive excess bond returns through the traditional Lucas channel for expected returns, as opposed to this speculative belief-driven channel, requires sufficiently high levels of risk aversion that cannot be empirically justified.
} 
markets and macroeconomic conditions using trading volumes of interest rate futures (i.e., third step of our main analysis). Applying principal component analysis, we extract two important principal components from our data (a pro-cyclical component and a counter-cyclical component) which are both linear combinations of the set of futures trading volumes. ${ }^{7}$ Us- $^{-}$ ing a vector autoregressive framework (VAR), we find that a factor built as the difference between these two components (pro- less counter-cyclical) strongly predicts higher equity returns and better performance by low-rated bonds. It also predicts higher GDP, consumption, and industrial production growth, as well as lower unemployment.

We take numerous steps to ensure the robustness of our results. First, our findings are qualitatively similar when using open interest in place of trading volume. As opposed to trading volume that captures the amount of trading activity in specific markets, open interest (i.e., the total number of outstanding contracts) captures the flow of capital into those markets and therefore provides an alternative dimension to observe investor preferences and market expectations. Second, our findings hold in various subsamples (portfolio deciles) and are not specific to times of crises that our sample captures. Third, we employ alternative measures for macroeconomic indicators (e.g., the National Activity Index by the Chicago Fed) and financial market health (NASDAQ and NYSE indexes) and continue to find support for our arguments.

In sum, we identify the economic difference between the trading volumes of short-term and long-term Treasury futures as a source of information about future conditions of financial markets and macroeconomic variables. Controlling for other commonly accepted predictors (e.g., default spread, term spread, aggregate dividend yield, etc.), the informational content of short-term and long-term futures volumes remains economically and statistically

\footnotetext{
${ }^{7}$ The pro- and counter-cyclical components are the second and first principals, respectively. Results from our analysis show that (i) these two principals explain $96.28 \%$ of the total variance in the full set of volume variables and that (ii) the first (i.e., counter-cyclical) component is largely driven by the 2-year and 5-year volumes, while the second (i.e., pro-cyclical) component is largely driven by the 30-year volume, hence the naming.
} 
significant. We argue that Treasury futures volume, when dissected by underlying maturity, contains information regarding the aggregate level of risk aversion accompanying differences in beliefs that incentivizes transactions among market participants.

Our study, to the best of our knowledge, is the first to differentiate between the information contents of short-term and long-term Treasury futures trading. We add to the line of research that examines horizon-dependent risk aversion (e.g., Andries et al., 2015; Eisenbach and Schmalz, 2015), the predictability of price and non-price statistics of interest rate futures on the macroeconomic conditions (Grossman, 1977; Samuelson, 1965; Hong and Yogo, 2012), and, more generally, the information content of trading volume (Blume et al., 1994).

We also contribute to the understanding of the relation between uncertainty and liquidity (Beber et al., 2009; Chung and Chuwonganant, 2014). ${ }^{8}$ Given the rising concerns among academics (Bloom et al., 2015; Pastor and Veronesi, 2011), practitioners (Galston, 2013; Vojdani, 2015; Shelton, 2015), and global facilitators (Lagarde, 2016a,b) regarding how uncertainty may impede economic growth, our results shed light on the understanding of the signaling power behind futures trading volumes. ${ }^{9}$

In the proceeding parts of this paper, we describe our data and sample in Section 2,

\footnotetext{
${ }^{8}$ Several studies, including Amihud and Mendelson (1991), Kamara (1994), and Strebulaev (2002), have conducted clean experiments on the pricing of liquidity using Treasury securities of different maturities. Other studies examine alternative dimensions. Krishnamurthy (2002), for instance, captures the liquidity premium using the spread between off-the-run and on-the-run U.S. Treasuries. Longstaff (2004) compares Treasury bond prices to REFCORP (Resolution Funding Corporation) bond prices.

${ }^{9}$ For the demand side of capital, business firms that face uncertainty may delay their potentially profitable investments due to the associated higher real option values (Ingersoll and Ross, 1992; Bloom et al., 2007). Severe information asymmetry problems may also impair their abilities to pursue profitable long-term projects (von Thadden, 1995) or to correctly determine the optimal level of investment (Bebchuk and Stole, 1993). Importantly, halts in corporate investments and hiring hinder the efficient allocation of capital and eventually slow down the economy (Bloom, 2009). For the supply side, assertion coincides with anecdotes that flight-to-liquidity phenomenon quickly result in panics that lead to a crisis. Following the Russian debt crisis in 1998, for example, many investors switched into holding on-the-run Treasury securities for liquidity. This led to a widened spread between off-the-run and on-the-run securities that ultimately contributed to the collapse of Long-Term Capital Management (LTCM) in the same year (Lowenstein, 2000). According to Ip (1998), former Chairman of the Federal Reserve Alan Greenspan described the phenomenon as investors saying, "I want out. I don't want to know anything about whether a particular investment is risky or not. I just want to disengage." This passage is later quoted by Blustein (2003) and Longstaff (2004), among many others.
} 
present our main analysis in Section 3 (including the validation of using volumes to capture risk aversion that accompanies differences in beliefs in Section 3.1 and the predictions of lead market and macroeconomic variables in Section 3.2), conduct robustness checks in Section 4, and conclude in Section 5.

\section{Data Sources and Sample}

Our key variables consist of Treasury futures volume, together with macroeconomic and financial indicators. Information on Treasury futures is from Bloomberg; data on financial markets are from Bloomberg and CRSP (Center for Research in Security Prices at Chicago Booth); macroeconomic variables are from FRED (Federal Reserve Economic Data provided by the St. Louis Fed). Our sample period is from December 1994 to August 2014. Due to the nature of our data, the analysis of excess returns on Treasury securities and capital markets is executed at monthly level, while the analysis of macroeconomic variables is executed on a quarterly basis. Raw volumes data from Bloomberg are in daily increments and are therefore aggregated either by month or by quarter for our estimations according to the time dimension of the dependent variable. Below, we provide details on our variables and sample construction, we introduce the main terminologies used in this paper, and we discuss the univariate evidence that provides first-glance support for our hypotheses.

\subsection{Treasury Futures Volume}

Our main explanatory variables are the trading volumes of a range of US Treasury futures contracts differentiated by the maturity of the underlying asset. From Bloomberg, we record daily volumes of futures contracts on the 2-, 5-, 10-, and 30-year Treasury securities over our sample period. For illustration purposes, we use the abbreviations "VOLUME2," "VOLUME5," "VOLUME10," and "VOLUME30" to denote the trading volumes of 2-year, 5-year, 
10-year, and 30-year Treasury futures throughout the paper, respectively. Additionally, we refer to volumes and interest rates as being "short-term" or "long-term" in a relative sense based on the four different maturities that we examine. For instance, the trading volume of futures contracts on 2-year Treasury securities is referred to as shorter-term relative to those on the 5-, 10-, and 30-year securities; the trading volume of futures contracts on 5-year Treasury securities is referred to as shorter-term relative to those on the 10- and 30-year securities; so on and so forth.

The contract size for 2-year T-Note futures is $\$ 200,000$ par of Treasury notes, while the contract sizes for 5-year, 10-year, and 30-year Treasury futures are $\$ 100,000$ par of Treasury notes/bonds. At any point in time, four different expiration dates are listed for a particular futures contract, being the last trading days of March, June, September, and December. The last trading day for each contract is the business day preceding the last 7 business days of the month; the last delivery day is the last business day of the delivery month.

When collecting daily data from Bloomberg, we employ the following procedure: For each day, the data represents trading in the nearby contract until the first delivery day, at which point the series switches over to the second nearby contract. Following Brandt et al. (2007), the trading activity in the delivery month is avoided because of settlement-induced illiquidity and the concentration of trading naturally shifting to the next nearby contract during that month. ${ }^{10}$ This procedure allows us to obtain a continuous daily series for futures contracts on the 2-, 5-, 10-, and 30-year US Treasuries. After obtaining trading volumes at the daily level, we aggregate them by either month or quarter, depending on the dependent variable for a particular estimation, in order for futures volume data to coincide in frequency with our market-specific excess returns (measured in monthly intervals) and macroeconomic variables (measured in quarterly intervals). Our final sample consists of 236 monthly (78 quarterly)

\footnotetext{
${ }^{10}$ For example, the data for December 1, 2000, through February 28, 2001, represents trading in the contract expiring in March 2001. From March 1, 2001, through May 31, 2001, the data represents trading in the contract expiring in June 2001. So on and so forth.
} 
observations that are available for multivariate estimations of lead dependent variables.

\subsection{Treasury Securities, Corporate Debt, Equity, and Macroeco- nomic Indicators}

We use three categories of dependent variables: The first captures yields and returns on the 2-, 5-, 10-, and 30-year Treasury securities. Data on Treasury yields are from FRED and historical Treasury returns are from CRSP. In addition to investigating the ability of our explanatory variables to predict Treasuries, we also use these variables to validate our interpretations of volume, as we discuss in the following section (Buraschi and Whelan, 2016; Xiong and Yan, 2010). The second category captures conditions of the corporate debt and equity capital markets and is from either CRSP or Bloomberg. We examine the corporate debt markets using the $\mathrm{AAA}, \mathrm{BBB}$, and $\mathrm{CCC}$ corporate bond returns based on the Bank of America/Merrill Lynch (BAML) US Corporate Effective Yield Indexes provided by FRED; we examine equity markets at the aggregate level using the overall CRSP value-weighted market index (VWRETD) and the S\&P 500 index (SP500). The third category contains variables that capture the conditions of the real economy and is from FRED. These include GDP growth (denoted as GGDP), consumption growth (GCONS), industrial production growth (GINDPRO), and unemployment growth (GUNEMP).

Figure 1 shows the evolution of trading activity for each of these contracts during our sample period. It is interesting to note the switch in importance between the 30-year and the 10-year treasury futures trading volume that happens sometime in the early 2000s. The beginning of this switch coincides with and may be partially driven by, the time period when 30-year Treasuries were discontinued (i.e., February 2002 to February 2006). It is also interesting to observe the large increase and subsequent drop in trading volume for all contracts around the financial crisis of 2007-2008. 
[Insert Figure 1 about here.]

Table I presents the descriptive statistics for our sample. The volume variables in the table are aggregated by month. We omit reporting quarterly volumes for space considerations, but they are available upon request. The volumes of Treasury futures contracts during our sample period possess characteristics that are in line with those reported in prior literature. For example, the 10-year Treasury futures contract is the most liquid and frequently traded. The average magnitude of volume appears to be monotonically increasing from the 2-year to 10 -year contracts, while the 30 -year contract has a volume similar to that of the 5-year contract. ${ }^{11}$ All dependent variables used in our main results are yields (for Treasury securities), returns (for both Treasury and corporate capital markets), or growth (for macroeconomic conditions) variables and are presented in percentages (see the Appendix for detailed descriptions).

[Insert Table I about here.]

\subsection{Univariate Evidence}

Table II shows the correlation matrix of variables used in this study. From the contemporaneous correlations reported, we make several observations. First, correlations between the volumes of the longest-term (30-year) and the two shorter-term (2- and 5-year) contracts are significantly lower than the those among the shorter-term contracts themselves (e.g., between the 2- and 5-year Treasury futures). This could be interpreted as the first evidence that the information captured by trading activities in long-term Treasury futures is different

\footnotetext{
${ }^{11}$ See, for example, the Treasury futures average daily volume graph presented by the CME Group (https://www.cmegroup.com/education/files/understanding-treasury-futures.pdf) or in Brandt et al. (2007, Table 1). Note that we present our volume variables at the monthly level in Table 1 due to the time dimension of the first two categories of our dependent variables, while these cited sources are presented at the daily level. Prior literature documents that the 30-year contract activity, relative to those of other horizons, has significantly dropped during the 1995-2000 period (as in Brandt et al., 2007, as well as evidence provided by the CME Group). Our data confirms this phenomenon.
} 
from that captured by its short-term counterpart. Second, in terms of the contemporaneous relation between Treasury futures trading and financial market indicators, there is generally a negative relation, which is consistent with the idea that when the equity and debt markets are doing well, there is a decrease in trading on the Treasury futures markets, reflecting lower levels of hedging demand. The correlations associated with short-term volumes, however, are of significantly larger economic magnitudes. Third, the trading volume in short-term contracts exhibits a counter-cyclical pattern at the univariate level, i.e., it is negatively correlated with variables that indicate good economic conditions (i.e., the growths of GDP, consumption, and industrial production) and positively correlated with those that indicate bad economic terms (i.e., unemployment growth). Oppositely, trading activity in long-term contracts shows a pro-cyclical pattern.

Since the volume variables appear to be highly correlated in many cases, we employ orthogonalized values of them in any of our multivariate models where multiple volume variables enter into a regression model simultaneously. The orthogonalization is performed using the modified Gram-Schmidt procedure (Golub and Van Loan, 2013).

[Insert Table II about here.]

It is important to note that Table II presents contemporaneous correlations. While these univariate relations are important for describing our data, they do not necessarily paint the relevant picture for the information that futures trading activity provides for future asset prices and macroeconomic conditions.

\section{Analysis}

In this section, we present the main results of this study. First, we provide empirical support that the futures trading volumes in short-term and long-term Treasury securities are indeed 
signaling risk aversion at the aggregate level. Second, we show that futures volumes predict the prices of debt and equity, and macroeconomic conditions. Third, we derive a common factor using trading volumes that contains information about the future performance of the Treasury, corporate debt, and equity markets, as well as about future macroeconomic conditions.

\subsection{Trading Volume, Risk Aversion, and Preference}

We interpret trading volume in a certain segment of the futures market (e.g., short-term or long-term) as a result of the combination of two drivers. First, as information arrives, market participants may process the information differently due to heterogeneous beliefs (Working, 1953; Grossman, 1975, 1977). Xiong and Yan (2010) suggest that such differences in beliefs facilitate transactions and thereby increase trading volume. Second, given the information content of short-term and long-term rates, investors' preferences for a certain segment of the market may be driven by their overall level of risk aversion. As investors transact in the Treasury futures market, they reveal their attitude towards risk, and in turn, convey information about market expectations regarding asset prices and macroeconomic conditions.

While empirical evidence shows that short-term rates and long-term rates move in tandem over time, suggesting that the latter is somewhat an average of sequential short-term spot and forward rates, price stickiness governs a large degree of how the actual risk-return relation of an economy is factored into the determination of rates (i.e., the economic fundamentals). ${ }^{12}$ Since the dissipation of price stickiness takes time, short-term rates would less likely reflect

\footnotetext{
${ }^{12}$ This property holds for the expectations theory and the liquidity preference theory of term structure. The time series rate movements of U.S. Government debt securities can be found in the H.15 releases of the Federal Reserve Board (http://www.federalreserve.gov/). As further support, there is an overall inverse relation between the level short-term rates and the slope of the yield curve. That is, although yield curves are almost always upward sloping, they are more likely to slope downward when short-term rates are high. Daily plots of the Treasury yield curve can be found in the "Money and Investing" section of the Wall Street Journal (Dow Jones \& Co., Inc.).
} 
economic fundamentals, but instead signal more about fluctuations in the demand and supply of money that are driven by the weighing of costs and benefits of holding money, as well as by monetary policies (Keynes, 1930, 1936). Long-term rates, oppositely, would more heavily reflect fundamentals such as market expectations of economic activity and productivity, as prices are more likely to become flexible over longer horizons.

These properties imply that larger volumes in short-term futures and in long-term futures convey economically different information: Trading volume in short-term (long-term) Treasury futures is more (less) likely driven by reactions of market participants to temporary uncertainties in the economic environment, signaling a lower (higher) level of overall risk aversion (Beber et al., 2009; Guiso et al., 2015).

Buraschi and Whelan (2016) provides a clean setting for us to validate our interpretation of trading volume in Treasury futures. Applying the theory of intertemporal consumption choices, they show the theoretical associations between the aggregate level of risk aversion and the yields and excess returns on Treasury securities. If trading volumes are indeed capturing investor preferences as we argue, then we should see those predictions when using short-term and long-term volumes to estimate Treasury yields and excess returns. ${ }^{13}$

According to Buraschi and Whelan's (2016) predictions, a lower level of risk aversion that accompanies differences in beliefs (as we proxy by short-term volume) encourages speculation and introduces higher expected returns. Under this situation, the higher endogenous quantity of risk from speculation lowers the present value of future consumption, therefore increasing the relative price of current consumption and hence encouraging savings. As a result, short-term rates drop since the substitution effect from less expensive future consumption dominates the income effect, where a drop in the price of future consumption also increases current consumption due to increased wealth (i.e., purchasing power). A higher

\footnotetext{
${ }^{13}$ Other recent studies have also linked risk aversion to consumption and savings, as well as monetary policy (Kimball and Weil, 2009; De Paoli and Zabczyk, 2013).
} 
level of risk aversion (as we proxy by long-term volume), oppositely, increases hedging demand and raises the drift of planned consumption today (i.e., the wealth effect dominates through the traditional channel of Lucas, 1978).

Therefore, we expect short-term (long-term) volume to be associated with lower (higher) interest rates. If both short-term rates and long-term rates are affected, we expect volumes to have a larger effect on the former relative to the latter. Consequently, the term spread would be inversely related to risk aversion, i.e., positively (negatively) related to short-term (long-term) volume. Further, low risk aversion levels along-side differences in beliefs (i.e., short-term volume) should have the power to predict positive excess bond returns and high risk aversion levels alongside differences in beliefs (i.e., long-term volume) should predict negative excess bond returns. ${ }^{14}$

[Insert Table III about here.]

In Table III, we report results from testing these implications. Panel A shows the results from estimating lead Treasury Yields, Panel B reports estimations of lead term spreads, and Panel C presents predictions of lead excess bond returns. The models take the following form:

$$
y_{t+1}=\mathbf{V}_{\mathbf{t}} \beta^{V}+\mathbf{C}_{\mathbf{t}} \beta^{C}+\epsilon_{t+1},
$$

where $y_{t+1}$ is one of our lead dependent variables (e.g., yields in Panel A). V is the matrix of orthogonalized volume variables that include the 2-, 5-, 10-, and 30-year futures trading volumes, where the orthogonalization is performed using the modified Gram-Schmidt procedure (Golub and Van Loan, 2013). For each panel, we report results for all 2-, 5-, 10-, and 30-year Treasuries. All models are estimated in monthly intervals and include commonly accepted predictors such as default spread (denoted as DEF) and aggregate dividend yield (DIV),

\footnotetext{
${ }^{14}$ This explains the empirical association between positive excess bond returns and insufficient risk aversion levels that cannot be justified under the traditional Lucas channel for expected returns (the equity premium puzzle). Instead, according to Buraschi and Whelan (2016), the phenomenon can be explained through a speculative belief-driven channel where differences in beliefs incentivizes agents to transact with each other.
} 
as captured by the matrix $\mathbf{C}$. The estimations of excess bond returns further incorporate term spread (TERM) and the risk-free rate (RF), which we proxy using the 1-year Treasury yield (Petkova and Zhang, 2005; Stivers and Sun, 2010). All models are reported using standardized beta coefficients with robust errors. The $t$-statistics in parentheses are corrected for autocorrelation and heteroscedasticity using the Newey and West (1987) estimator with three lags.

In Panel B, a term spread is calculated using the yield on the Treasury security with a maturity as the specific model name implies (e.g., TERM30 uses the 30-year Treasury yield), benchmarked by the 1-year yield. The excess bond returns in Panel $\mathrm{C}$ use the realized returns on a given Treasury security with a maturity specified by the model name (e.g., B30 uses the 30-year Treasury return) benchmarked using the 1-year yield.

Overall, we find what we expect: The trading volumes of short-term (long-term) interest rate futures are associated with lower (higher) bond yields (Panel A), larger (smaller) term spreads (Panel B), and higher (lower) Treasury excess returns (Panel C). Thus, we validate our interpretation of trading volumes for Treasury futures of different maturities of the underlying asset signaling the aggregate level of risk aversion that accompanies the differences in beliefs among market participants.

\subsection{Futures Volumes and the Real and Financial Markets}

\subsubsection{The Effects of Volumes}

We start our multivariate analysis by separately examining the predicting powers of the 2-, 5-, 10-, and 30-year Treasury futures volumes on financial markets and the real economy. Based on our earlier arguments, we expect the relatively short-term Treasury futures volume to be counter-cyclical (i.e., it should precede inferior market performances and economic contractions) and the long-term volume to be pro-cyclical (i.e., associated with better market 
performances and economic expansions). We propose that the maturity of the underlying asset for Treasury futures volume contains additional information about the real economy and financial markets on top of existing, commonly accepted predictors (see Petkova and Zhang, 2005; Stivers and Sun, 2010; Chichernea et al., 2015). To test this, we use the following model:

$$
y_{t+1}=\mathbf{V}_{\mathbf{t}} \beta^{V}+\mathbf{C}_{\mathbf{t}} \beta^{C}+\epsilon_{t+1},
$$

where $y_{t+1}$ is one of our lead indicators for financial market conditions and macroeconomic indicators. For equity markets, we consider the CRSP value-weighted market return and the S\&P 500 index return; for corporate debt markets, we consider the AAA, BBB, and CCC bond returns calculated using the Bank of America/Merril Lynch (BAML) Index; for macroeconomic conditions, we consider the growths in GDP, consumption, industrial production, and unemployment. $\mathbf{V}$ is the matrix of volume variables that include the 2-, 5-, 10-, and 30-year orthogonal futures trading volumes; $\mathbf{C}$ is the matrix of control variables, including default spread (abbreviated as DEF), term spread (TERM), yield on the 1-year Treasury (RF), and aggregate dividend yield (DIV).

We report the results for the predictions of excess returns for corporate equity and debt in Table IV and the results for macroeconomic forecasts in Table V. The corresponding $t$ statistics in parentheses are corrected for autocorrelation and heteroscedasticity using the Newey and West (1987) estimator with three lags. All models are reported using standardized beta coefficients with robust errors.

[Insert Table IV about here.]

Table IV tests the relation between the volumes of futures with different maturities and the performance of financial markets. Columns (1) and (2) show that if the short-term (long-term) volumes increase, aggregate equity returns are expected to decrease (increase) in the next period. Note that on average the magnitude of short-term futures effect is higher 
than the effect of long-term futures. It is consistent with the idea that risk tolerant investors are more sensitive to negative news. Columns (3) to (5) present the same analysis, but for the credit market. Interestingly, we only see effects that are consistent with those reported earlier in the CCC corporate bonds model (column (5)), where economic uncertainty is most relevant. AAA and BBB bonds, in contrast, do not yield a clear pattern. This result is in line with the notion that high-risk debt has equity-like properties (Schaefer and Strebulaev, 2008).

[Insert Table V about here.]

In Table V, we test whether movements in Treasury futures volume with different maturity predict real economic activity by estimating time-series regressions of macroeconomic indicators using trading volumes as the key explanatory variables. In column (1), we estimate the GDP growth model, where the dependent variables are the full orthogonalized set of 2-, 5-, 10-, and 30-year futures volumes and all controls. According to the results presented in this table, we observe that, while the variables capturing the relatively short-term volumes (2-year and 5-year) are counter-cyclical, those capturing long-term volumes (10-year and 30year) are pro-cyclical. For example, VOLUME2 (VOLUME30) predicts GDP growth with a coefficient of $-0.48(0.39)$, with a $t$-statistic of -3.83 (4.42). The negative (positive) estimated coefficient for the short-term (long-term) futures volume suggests that GDP growth is expected to be lower (higher) for the calendar quarter immediately following the volume variables. In columns (2) and (3) of Table $\mathrm{V}$, we estimate the effect of the futures volume on consumption growth (GCONS) and industrial production growth (GINDPRO). The results are overall similar to those found for the GDP growth model. Finally, column (4) presents the estimation of unemployment growth. As expected, we find that the shorter-term (longerterm) volumes are associated with higher (lower) future unemployment growth (however, the VOLUME2 coefficient estimate for this model is insignificant ${ }^{15}$, reflecting weaker short-term

\footnotetext{
${ }^{15}$ We obtain slightly better results when we use the change rather than the growth in the unemployment
} 
results for growth in unemployment).

\subsubsection{Single Factor in the Vector Autoregressive Framework}

Next, we use the set of volume variables to derive a single factor that bears predicting power across the Treasury, corporate debt, and equity markets, as well as for macroeconomic indicators. This one-factor estimation consists of two stages: In the first stage, we derive a linear combination of volumes as the factor; in the second stage, we use this factor as the predictor for different market returns and macroeconomic indicators.

This exercise is analogous in spirit with Cochrane and Piazzesi (2005), but since our dependent variables (including excess returns on Treasury securities, corporate bonds, and stocks and growths of GDP, aggregate consumption, industrial production, and unemployment) are of different natures and span across different markets, we do not use a first-stage target variable that is composed of specific rates or returns. Rather, we directly extract information from the set of volume variables using principal components analysis (Hotelling, 1933; Jackson, 2005; Jolliffe, 2002). ${ }^{16}$

At the initial stage, we examine all four principals. The eigenvalues of the correlation matrix are reported in Panel A of Table VI. The corresponding eigenvectors are not reported, but available upon request. From the eigenvalues, we see that the first principal component has a variance of 2.915, which explains almost $73 \%$ (i.e., 2.915/4) of the total variance. Notably, the first two components together explain $96.3 \%$ of total variance of the four volume variables.

[Insert Table VI about here.]

In Panel B of Table VI, we further examine how each of the four principal components

variable (note that this series is already expressed in percentages).

${ }^{16} \mathrm{By}$ construction, principle components are unit-length linear combinations of the volume variables and are uncorrelated with one another. Therefore, unlike the regression results reported earlier, we do not use orthogonal volumes for this part of the analysis. 
correlates with the raw volume variables. We find that the 2-, 5-, and 10- year volumes are highly correlated with the first principal component (PC1) and that the 30-year volume is highly correlated with the second principal component (PC2). Based on these results, we refer to the first and second principal components, which together have explanatory power for $96.3 \%$ of total variance of all volumes, as the "counter-cyclical" and "pro-cyclical" components, respectively. We further take the difference between the pro- and countercyclical components and use it as our single volume factor that represents the entire set of four volume variables. ${ }^{17}$

Moving forward, in order to further control for the interdependencies among time-series processes associated with our data, we employ a vector autoregressive (VAR) system. Let $z_{t}$ be a vector of variables describing the economy at time $t$. We then estimate a VAR system of the following form:

$$
z_{t+1}=\Gamma z_{t}+u_{t+1}
$$

The matrix $\boldsymbol{\Gamma}$ contains the estimates of the system. In all our systems to be estimated, the first element of the $z_{t}$ vector is one of the aforementioned indicators of financial market performance or macroeconomic condition (e.g., the growth in GDP), and the second element is the single volume factor (PC). The next four elements are control variables, as described earlier, including default spread (abbreviated as DEF), term spread (TERM), yield on the 1year Treasury $(\mathrm{RF})$, and aggregate dividend yield (DIV). To ensure that the system is stable, we confirm that the modulus of each eigenvalue of $\boldsymbol{\Gamma}$ is strictly less than one (Hamilton, 1994).

The vector-autoregressive (VAR) systems for Treasury excess returns, corporate equity and debt excess returns, and macroeconomic variables are reported in Tables VII, VIII, and

\footnotetext{
${ }^{17}$ In an earlier version of the paper, we use an alternative single factor, which we refer to as the VDIFF, simply defined as the difference between the 30- and 2-year trading volumes. While we were able to obtain qualitatively similar results as reported in the current version that uses principal components, it is largely due to the monotonicity nature of the data. As we see from the regression results reported, the shorter-term (longer-term) the maturity, the more counter-cyclical (pro-cyclical) the volume. Taking a simple difference, however, does not economically justify not using the 5 - and 10-year volumes.
} 
IX, respectively. All models are reported using standardized beta coefficients with robust errors. Based on earlier results, we expect the single volume factor (PC) to be able to predict the future performance of the financial markets and real economic activity. In the VAR estimations, we are primarily interested in the first column in each $\Gamma$ matrix, which shows the standardized coefficient estimates for the volume factor and other covariates.

In Table VII, we see that a larger volume factor, i.e., a larger difference between the pro- and counter-cyclical components of volume, predicts lower Treasury excess returns (the coefficients on $\operatorname{lag} P C$ are negative and significant in all panels). This is consistent with our earlier findings reported in Table III and also reaffirms our interpretations of volume conveying information regarding investor expectations, differences in beliefs, and the underlying risk preferences that drive intertemporal consumption decisions (Buraschi and Whelan, 2016).

[Insert Table VII about here.]

In Table VIII, we further test whether the volume PC factor is significantly associated with the performances of the equity and debt capital markets looking forward (in excess of the risk free rate). We see from Panels A and B that the volume factor and dividend yield variables positively and significantly predict equity market returns. The estimated coefficients for PC are 0.31 and 0.33 for the value-weighted CRSP (VWRET) and S\&P 500 (SP500) indexes, respectively. The same pair of coefficients for DIV are 0.17 and 0.19. Holding all else constant, a one-standard-deviation increase in the difference between the pro- and counter-cyclical components of Treasury futures volume predicts increases in the returns on the VWRET index and the SP500 portfolio by 0.31 and 0.33 standard deviations over the next quarter, respectively.

[Insert Table VIII about here.] 
In Panels $\mathrm{C}$ and $\mathrm{D}$ of Table VIII, we report results from the VAR estimates for the performances of the corporate bonds market. In this case, the futures volume difference still positively predicts the performance of the high distress corporate bonds portfolio (CCC) but does not predict the performance of the safer corporate bond index (AAA). Consistent with earlier findings in our time series analyses, the volume difference positively predicts the returns on CCC corporate portfolio. Again, this is consistent with our argument that the CCC bonds present the portion of the public debt market where uncertainty is most relevant. This is also in-line with the idea that AAA-grade bonds do not present a good investment during economic expansions. If anything, investors are more likely to close this low risk and returns positions and to search for better opportunities.

Finally, we focus on the analysis of real economic activity. Specifically, we investigate whether the difference in the pro- and counter-cyclical components (PC) of futures trading volume can predict growth in GDP (GGDP), aggregate consumption (GCONS), industrial production (GINDPRO), and unemployment (GUNEMP) using the VAR approach. This analysis is presented in Table IX.

\section{[Insert Table IX about here.]}

Panel A of Table IX presents the analysis for GGDP. Consistent with the estimations of debt and equity capital market excess returns, we document that our futures trading factor is positively associated with GDP growth (the estimated standardized coefficient is 0.62 and is significant at $1 \%$ level). At the same time, higher values of default spread are more likely to be associated with a decrease in GDP growth after controlling for other commonly accepted macroeconomic covariates.

We repeat the same analysis for the other variables capturing real economic activity. In each case, PC is consistently pro-cyclical and significantly predicts the macroeconomic indicator of the following calendar quarter. According to Panels B and C of Table IX, 
the standardized coefficient estimates of PC for GCONS and GINDPRO are 0.65 and 0.37, respectively - both statistically significant at the $1 \%$ level. Intuitively, a one-standarddeviation increase in the volume factor predicts an almost 0.7 increase in the standard deviation of GDP growth and a 0.37 standard-deviation increase in consumption growth, holding all else equal. Similarly, Panel D of Table IX shows that the volume factor tends to decrease unemployment growth, which is consistent with the notion of PC being pro-cyclical and having predictive power.

Throughout most specifications in Table IX, default spread also consistently and significantly predicts lead real economic activity, with the estimation of industrial production being the only exception. It is, however, a counter-cyclical variable. That is, a higher DEF on average is associated with a decrease in real economic activity.

To sum, our volume factor, i.e., the difference between the pro- and counter-cyclical components derived from principals of Treasury futures trading volumes, is a pro-cyclical variable that consistently predicts lead Treasury excess returns, lead performance of the financial markets, and future real economic activity even after controlling for other commonly accepted macroeconomic factors.

\subsection{Forecasting results: How long and how accurate?}

To investigate the length of the Treasury futures volume forecast we run predictive regressions, where the timing of our dependent variable is set to 1 through 6,9 , and 12 months (quarters) ahead for the excess returns of the Treasury, equity, and corporate debt markets (macroeconomic variables). To ensure that the predictability is not driven by other macroeconomic variables, we also include the matrix of all aforementioned controls. We estimate the following equation:

$$
y_{t+\tau}=\beta_{0}+\beta_{1} P C_{t}+\beta^{C} \mathbf{C}_{t}+\epsilon_{t+\tau},
$$


where $y_{t+\tau}$ is the lead financial markets or macroeconomic variable. $\tau$ presents the number of months or quarters ahead, depending on the time dimension of the dependent variable. PC, the single volume factor, is defined as the difference between the pro- and counter-cyclical components derived from principals of Treasury futures trading volumes. As before, the matrix of controls $\mathbf{C}$ includes default spread (abbreviated as DEF), term spread (TERM), yield on the 1-year Treasury (RF), and aggregate dividend yield (DIV). The corresponding $t$-statistics are based on standard errors adjusted for autocorrelation and heteroscedasticity using the Newey and West (1987) estimator with three lags.

\section{[Insert Table X about here.]}

Table $\mathrm{X}$ presents the results from this analysis. In the first four models, we see that PC bears predictability for Treasury excess returns for up to five months forward, whereas for equity (as shown in the 5th and 6th models) the forecasting power goes as far as six to twelve months ahead, depending on the exact dependent variable being estimated. In the VWRETD model, for instance, the estimated coefficients for PC remain significant up to the sixth month; for the SP500 model, the forecasting power lasts up to the twelfth month (but only at the $10 \%$ level).

With respect to the corporate debt market, we observe that the high-risk (CCC) index return can be forecasted by the futures volume factor for five months looking forward. As in previous analyses, we do not see any obvious pattern in PC as an explanatory variable for AAA bond returns.

We also document strong predictability for the volume factor with respect to growth in various macroeconomic indicators. According to the results presented in the table, PC consistently and significantly forecasts future real economic activity over the next six quarters (one and a half years). In the case of the real economic activity (the bottom four models), the predictive power of the forecast holds for at least the one and a half years and persists 
after that in the case of consumption growth.

In untabulated results, we conduct out-of-sample forecasts. The analysis is similar to that seen in Ang et al. (2006). We use the 1995 to 2014 sample period to obtain forecasts based on stable estimates from rolling windows of 36 quarters. Specifically, we first estimate the model parameters using Equation (2) between 1995:Q1 to 2003:Q4 (i.e., the first nine sample years), and then use them to forecast the dependent variable of the following quarter. For each subsequent calendar quarter, we employ the same methodology by moving the estimation window one quarter ahead. As a result, for each calendar quarter $t$, we form out-of-sample forecasts for the dependent variables using the same number of observations up to the quarter prior. The out-of-sample period spans from 2004:Q1 to 2014:Q2, which covers more than ten years and incorporates the sub-prime mortgage crisis period. In addition to the one-step forecasts described above, we also employ 2-4 step forecasts to ensure robustness and obtain qualitatively similar results. Overall, both our predictive regressions and our (untabulated) out-of-sample forecasts show that Treasury futures volume can be used to successfully predict future growth in real and financial markets.

\section{Robustness Checks}

We run a battery of robustness checks to ensure the strength of our results. We generally categorize our checks into two broad categories: The first deals with alternative measures of Treasury futures trading activity (e.g., open interest rather than volume) and the second deals with alternative measures of financial markets conditions and macroeconomic activity. The empirical results for this section of the paper are not tabulated due to space concerns, but are available upon request. 


\subsection{Futures Open Interest}

Our results suggest that the relative importance of long and short term trading activity in the Treasury futures markets contains important information about future economic and financial conditions. Specifically, relatively more long-term Treasury futures trading activity is pro-cyclical, while short-term activity likely predicts bad times (i.e. it is counter-cyclical). Our main results illustrate this point using either the set of orthogonal volume variables separately (VOLUME2-VOLUME30) or the single volume factor derived from principal components (PC).

To ensure that our conclusion is not driven by the particular proxy that we use for futures trading activity (i.e. volume), we repeat our main results using open interest as an alternative measure (Hong and Yogo, 2012). Specifically, we reestimate our main models using open interest data, where we introduce an alternative measure, OIDIFF, as the difference between the long-term and short-term open interest (OIDIFF). We then use this variable as the second element of a VAR system describing the economic conditions (similar to the VAR system described in equation 3 with the corresponding results in Table IX). Our results remain qualitatively similar to those reported earlier.

Similar to the factor derived based on Treasury volumes, the difference between longterm and short-term open interest is consistently pro-cyclical and significantly predicts most of next quarter's economic variables considered. The results of the VAR system also show that the difference between long- and short-term open interest, as in the case of volumes, contains useful information in predicting the future financial market conditions. The results are consistent with those reported earlier using volumes. Specifically, similar to the volume factor, the difference in Treasury futures open interest positively and significantly predicts the equity market returns, as well as the CCC bond market index.

Overall, the results presented in this section help support our claim that, regardless of the proxy used to measure the relative importance of long and short term trading activity 
in the Treasury futures markets, this variable contains relevant information which can help us predict future economic and financial activity.

\subsection{Alternative Measures of Economic and Financial Activity}

Our main results pertain to proxies measuring growth in the main economic indicators (GDP, consumption, industrial production, and unemployment). For robustness, we also investigate an alternative measure of economic activity - the Chicago Fed National Activity Index (CFNAI). In short, the CFNAI is the weighted average of 85 existing monthly indicators of national economic activity, drawn from broad categories that describe (i) production and income, (ii) employment, unemployment, and hours, (iii) personal consumption and housing, and (iv) sales, orders, and inventories. ${ }^{18}$ We observe the same pattern in the predictive behavior of long- and short-term futures trading activity - an increase in trading activity for the 30-year (2-year) Treasury futures predicts high (low) levels of CFNAI, meaning that long-term (short-term) futures trading activity acts as a strong pro-cyclical (counter-cyclical) variable.

Additionally, in terms of financial markets activity, we investigate whether our results regarding the stock market are robust for large and small stocks by using alternative benchmarks for stock market performance. Specifically, we look at the NASDAQ and NYSE indices, as well as at the smallest and largest deciles of stocks traded on each one of these markets. The results using the NASDAQ and NYSE indices support our earlier main results from Table IV.

Interestingly, when we isolate the smallest and largest deciles from each market (NS-

\footnotetext{
${ }^{18}$ The CFNAI is available at the Federal Reserve Bank of Chicago (https://www.chicagofed.org/publications/cfnai/index). The index is constructed to have a mean of zero and a standard deviation of one. Based on the data description provided by the Chicago Fed, "Since economic activity tends toward trend growth rate over time, a positive index reading corresponds to growth above trend and a negative index reading corresponds to growth below trend." The CFNAI corresponds conceptually to the economic activity index developed by Stock and Watson (1999).
} 
DAQ1/NSDAQ10, and NYSE1/NYSE10, respectively), we observe that the strong predictive power of the long-term volume variable seems to be driven by the effect on the largest firms for example, the coefficient for VOLUME30 is positive and significant for the largest deciles of NYSE and NASDAQ firms (4.08 and 9.40, with a $t$-statistic of 3.4 and 2.97, respectively); at the same time, this coefficient is not significantly different from 0 for the smallest deciles of firms. In contrast, the short-term volume variables seem to have a significant (negative) relation with future returns of both large and small stocks.

\subsection{Additional robustness checks}

We take a number of additional steps to ensure the robustness of our results. Our first concern stems from the apparent change in relative importance of trading activity of the 10-year and 30-year contract pre- and post- 2000 (although the 30-year contracts had the highest volume in the early sample, after 2000 the 10-year contracts gain the first place see discussion in Footnote 8). We repeat our main analysis using the sample after 2000 and reach qualitatively similar conclusions.

Our second concern is whether the uncertainty generated by the financial crisis affected trading activity in the futures markets and, therefore, including the financial crisis years may bias our results. We drop years 2008 and 2009 from our sample and repeat our main tests. According to the untabulated results, we continue to document the same trends. Overall, the results are qualitatively similar in this case.

We confirm that the relation between trading volume and economic/financial activity is robust to our use of controls by repeating our main tests as base models (without the inclusion of controls). We also confirm that our difference results are not driven by the short- or long- term side of the equation by using one type of maturity contract at a time with qualitatively similar conclusions. Also, given that the face value of the 2-year futures contracts is double the face value of 30-year contracts, we repeat the analysis using the face 
value (amount traded) as a proxy for trading activity in the Treasury futures market and confirm our results.

One final concern relates to our interpretation of volume as a proxy for disagreement of opinion (and further more, the aggregate level of risk aversion for different segments of the market). One could think of alternative interpretations of our results - for example, the connection between volatility and volume could be explaining our results, albeit one would have to justify the differential channels for long- and short-term volumes through a volatility story (however, according to the Xiong and Yan (2010) model, divergence of opinion generates both volatility and volume so a relation between the two is to be expected). Preliminary results do show a strong connection between general volatility measures (e.g. VIX) and our volume series, especially for the 2- and 30-year volumes. Although we acknowledge that the connection between volatility and volume in the Treasury futures markets could prove to be a very interesting research area, we leave that to future research in order to not confound the focus of this paper.

\section{Conclusions}

In this study, we document that Treasury futures volume is generated by differences in investors beliefs. More importantly, we show that information contained in the futures volume varies with a maturity of the underlying Treasury contracts. Specifically, we find that a larger volume in short-term (long-term) Treasury futures is counter-cyclical (procyclical), as it precedes worse (better) performances of debt and equity capital markets and deteriorating (improving) conditions of the economy. Controlling for other commonly accepted predictors, the informational content of short-term and long-term futures volumes remains economically and statistically significant. We argue that Treasury futures volume, when dissected by underlying maturity, contains information regarding the aggregate level of 
risk aversion accompanying differences in beliefs that incentivizes transactions among market participants. 


\section{References}

Amihud, Yacov, and Haim Mendelson, 1991, Liquidity, maturity, and the yield on US Treasury securities, Journal of Finance 46, 479-486.

Andries, Marianne, Thomas M. Eisenbach, and Martin C. Schmalz, 2015, Asset pricing with horizon-dependent risk aversion, Toulouse School of Economics working paper.

Ang, Andrew, Monika Piazzesi, and Min Wei, 2006, What does the yield curve tell us about GDP growth?, Journal of Econometrics 131, 359-403.

Bebchuk, Lucian Arye, and Lars A. Stole, 1993, Do short-term objectives lead to underinvestment or overinvestment in long-term projects, Journal of Finance 48, 719-729.

Beber, Alessandro, Michael W. Brandt, and Kenneth A. Kavajecz, 2009, Flight-to-quality or flight-to-liquidity? Evidence from the euro-area bond market, Review of Financial Studies $22,925-957$.

Bennett, James A., Richard W. Sias, and Laura T. Starks, 2003, Greener pastures and the impact of dynamic institutional preferences, Review of Financial Studies 16, 1203-1238.

Bloom, Nicholas, 2009, The impact of uncertainty shocks, Econometrica 77, 623-685.

Bloom, Nicholas, Scott R. Baker, and Steven J. Davis, 2015, Measuring economic policy uncertainty, NBER working paper.

Bloom, Nicholas, Stephen Bond, and John Van Reenen, 2007, Uncertainty and investment dynamics, Review of Economic Studies 74, 391-415.

Blume, Lawrence, David Easley, and Maureen O'Hara, 1994, Market statistics and technical analysis: The role of volume, Journal of Finance 49, 153-181. 
Blustein, Paul, 2003, The Chastening: Inside the Crisis that Rocked the Global Financial System and Humbled the IMF. (PublicAffairs).

Brandt, Michael W., Kenneth A. Kavajecz, and Shane E. Underwood, 2007, Price discovery in the Treasury futures market, Journal of Futures Markets 27, 1021-1051.

Buraschi, Andrea, and Paul Whelan, 2016, Speculation, hedging, and interest rates, Imperial College London working paper.

Carlton, Dennis W., 1984, Futures markets: Their purpose, their history, their growth, their successes and failures, Journal of Futures Markets 4, 237-271.

Chichernea, Doina C, Anthony D Holder, and Alex Petkevich, 2015, Does return dispersion explain the accrual and investment anomalies?, Journal of Accounting and Economics 60, $133-148$.

Chung, Kee H., and Chairat Chuwonganant, 2014, Uncertainty, market structure, and liquidity, Journal of Financial Economics 113, 476-499.

Cochrane, John H., and Monika Piazzesi, 2005, Bond risk premia, Journal of Finance 95, $138-160$.

Cornell, Bradford, 1981, The relationship between volume and price variability in futures markets, Journal of Futures Markets 1, 303-316.

De Paoli, Bianca, and Pawel Zabczyk, 2013, Cyclical risk aversion, precautionary saving, and monetary policy, Journal of Money, Credit and Banking 45, 1-36.

Ehling, Paul, Michael Gallmeyer, Christian Heyerdahl-Larsen, and Philipp Illeditsch, 2017, Disagreement about inflation and the yield curve, Journal of Financial Economics forthcoming. 
Eisenbach, Thomas M., and Martin C. Schmalz, 2015, Asset pricing with horizon-dependent risk aversion, Federal Reserve Bank of New York working paper.

Falkenstein, Eric G., 1996, Preferences for stock characteristics as revealed by mutual fund portfolio holdings, Journal of Finance 51, 111-135.

Galston, William A., 2013, Policy uncertainty paralyzes the economy, Wall Street Journal Politics and Ideas, Sept. 24.

Golub, Gene H., and Charles F. Van Loan, 2013, Matrix Computations. (Johns Hopkins University Press) 4 edn.

Grammatikos, Theoharry, and Anthony Saunders, 1986, Futures price variability: A test of maturity and volume effects, Journal of Business 59, 319-330.

Grossman, Sanford J., 1975, Rational expectations and the econometric modeling of markets subject to uncertainty: A bayesian approach, Journal of Econometrics 3, 255-272.

Grossman, Sanford J., 1977, The existence of futures markets, noisy rational expectations and informational externalities, Review of Economic Studies 44, 431-449.

Guiso, Luigi, Paola Sapienza, and Luigi Zingales, 2015, Time varying risk aversion, Center for Economic and Policy Research working paper.

Hamilton, James D., 1994, Time Series Analysis. (Princeton University Press).

Hamilton, James D., 2009, Daily changes in Fed funds futures prices, Journal of Money, Credit and Banking 41, 567-582.

Hicks, John R., 1946, Value and Capital: An Inquiry Into Some Fundamental Principles of Economic Theory. (Clarendon Press). 
Hong, Harrison, David Sraer, and Jialin Yu, 2017, Inflation bets on the long bond, Review of Financial Studies 30, 900-947.

Hong, Harrison, and Motohiro Yogo, 2012, What does futures market interest tell us about the macroeconomy and asset prices?, Journal of Financial Economics 105, 473-490.

Hotelling, Harold, 1933, Analysis of a complex of statistical variables into principal components, Journal of Educational Psychology 24, 417-441.

Ingersoll, Jonathan E., Jr., and Stephen A. Ross, 1992, Waiting to invest: Investment and uncertainty, Journal of Business 65, 1-29.

Ip, Greg, 1998, Illiquidity is crippling the world of bonds, Wall Street Journal Credit Markets, Oct. 19.

Jackson, J. Edward, 2005, A User's Guide to Principal Components. (John Wiley \& Sons).

Jegadeesh, Narasimhan, and George G. Pennacchi, 1996, The behavior of interest rates implied by the term structure of eurodollar futures, Journal of Money, Credit and Banking $28,426-446$.

Jolliffe, Ian, 2002, Principal Component Analysis. (Springer) 2 edn.

Kamara, Avraham, 1994, Liquidity, taxes, and short-term treasury yields, Journal of Financial and Quantitative Analysis 29, 403-417.

Keynes, John Maynard, 1930, A Treatise on Money. (Martino Fine Books).

Keynes, John Maynard, 1936, The General Theory of Employment, Interest, and Money. (Palgrave Macmillan).

Kimball, Miles, and Philippe Weil, 2009, Precautionary saving and consumption smoothing across time and possibilities, Journal of Money, Credit and Banking 41, 245-284. 
Krishnamurthy, Arvind, 2002, The bond/old-bond spread, Journal of Financial Economics $66,463-506$.

Krugman, Paul, and Robin Wells, 2012, Macroeconomics. (Worth Publishers).

Lagarde, Christine, 2016a, The transitions of 2016, Project Syndicate p. Jan. 5.

Lagarde, Christine, 2016b, What does 2016 hold for the global economy?, World Economic Forum p. Jan. 6.

Longstaff, Francis A., 2004, The flight-to-liquidity premium in US Treasury bond prices, Journal of Business 77, 511-526.

Lowenstein, Roger, 2000, When Genius Failed: The Rise and Fall of Long-Term Capital Management. (Random House).

Lucas, Robert E., Jr., 1978, Asset prices in an exchange economy, Econometrica.

Martell, Terrence F., and Avner S. Wolf, 1987, Determinants of trading volume in futures markets, Journal of Futures Markets 7, 233-244.

Morgenson, Gretchen, and Campbell R. Harvey, 2002, The New York Times Dictionary of Money and Investing: The Essential A-to-Z Guide to the Language of the New Market. (Times Books).

Newey, Whitney K., and Kenneth D. West, 1987, A simple positive definite, heteroscedasticity and autocorrelation consistent covariance matrix, Econometrica 55, 703-705.

Pastor, Lubos, and Pietro Veronesi, 2011, Uncertainty about government policy and stock prices, University of Chicago working paper.

Patinkin, Don, 1987, Neutrality of Money, from The New Palgrave: A Dictionary of Economics. (Palgrave Macmillan). 
Petkova, Ralitsa, and Lu Zhang, 2005, Is value riskier than growth?, Journal of Financial Economics 78, 187-202.

Samuelson, Paul A., 1965, Proof that properly anticipated prices fluctuate randomly, Industrial Management Review 6, 41-49.

Schaefer, Stephen M, and Ilya A Strebulaev, 2008, Structural models of credit risk are useful: Evidence from hedge ratios on corporate bonds, Journal of Financial Economics 90, 1-19.

Shelton, Judy, 2015, The fed, killing economic growth softly, The Hill Contributors, Sept. 22.

Stivers, Chris, and Licheng Sun, 2010, Cross-sectional return dispersion and time variation in value and momentum premiums, Journal of Financial and Quantitative Analysis 45, 987-1014.

Stock, James H., and Mark W. Watson, 1999, Forecasting inflation, Journal of Monetary Economics 44, 293-335.

Strebulaev, Ilya A., 2002, Many faces of liquidity and asset pricing: Evidence from the US Treasury securities market, Stanford Univerity working paper.

Tauchen, George, and Mark Pitts, 1983, The price variability-volume relationship on speculative markets, Econometrica 51, 485-505.

Vojdani, Masood, 2015, Long-term thinking about short-term interest rates, U.S. News $\mathscr{E}$ World Report Money - The Smart Investor, Sept. 14.

von Thadden, Ernst-Ludwig, 1995, Long term contracts, short term investment and monitoring, Review of Economic Studies 62, 557-575. 
Working, Holbrook, 1953, Futures trading and hedging, American Economic Review 43, 314-343.

Xiong, Wei, and Hongjun Yan, 2010, Heterogeneous expectations and bond markets, Review of Financial Studies 23, 1433-1466. 


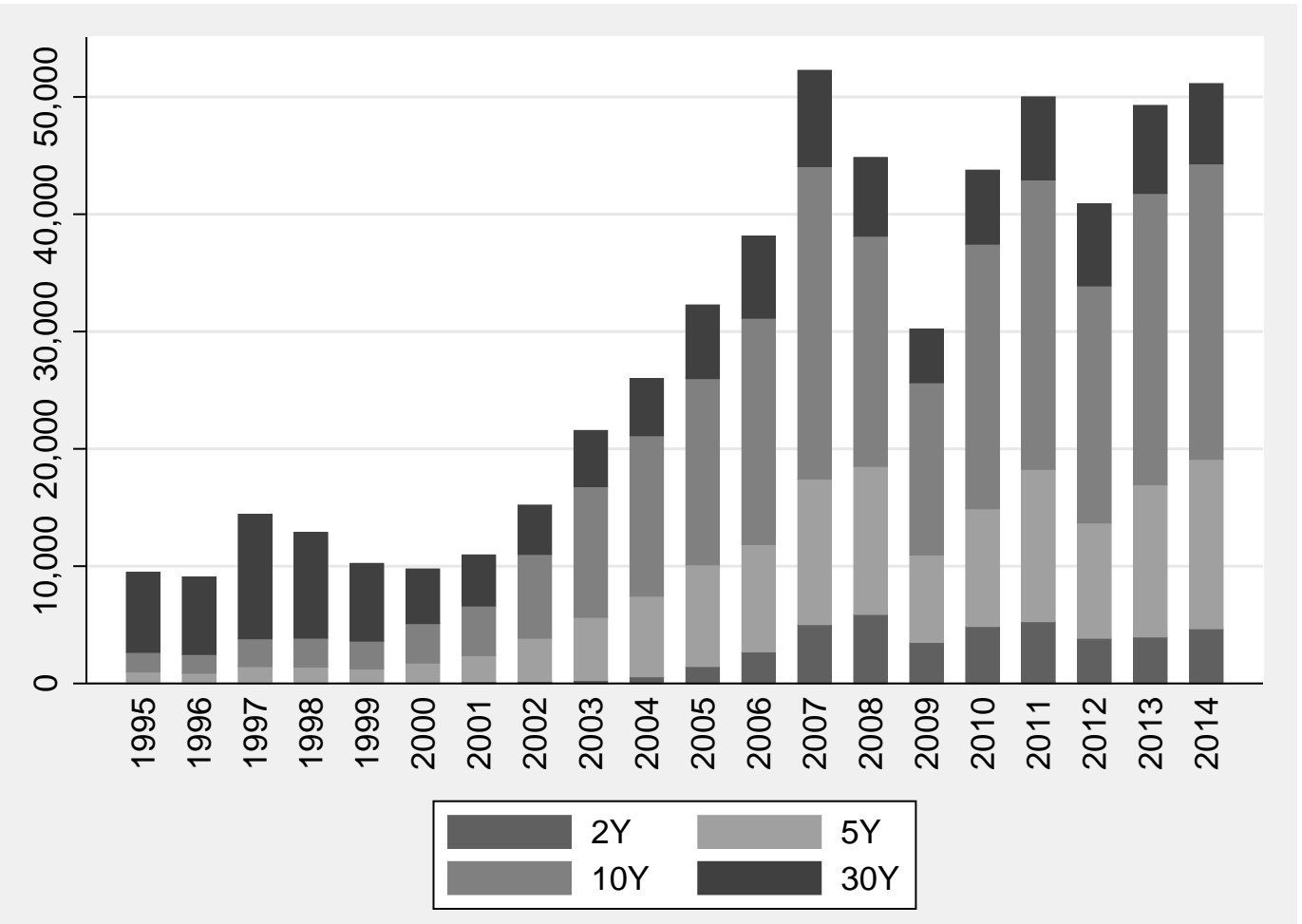

Figure 1: Treasury futures trading volume. This figure presents the time-series evolution of the yearly aggregate trading volume for the 2-, 5-, 10- and 30-year treasury futures contracts. The volume figures are quoted in 1000s of contracts for the nearby future. Variable definitions can be found in Appendix A. 
Table I: Summary statistics

This table shows the descriptive statistics of variables used in the study. The definition and construction details for each variable can be found in Appendix A. The futures contracts volume characteristics are monthly and quoted in 1000s of contracts for the nearby future. All returns variables are in excess of the risk free rate and are expressed in monthly percentages. All macroeconomic variables are expressed in quarterly percentages. The sample period is from January 1995 to July 2014 (for a total of 236 months or 78 quarters, respectively).

\begin{tabular}{|c|c|c|c|c|c|c|c|}
\hline & MEAN & STD & P10 & P25 & Median & P75 & P90 \\
\hline \multicolumn{8}{|c|}{ Futures Contracts Characteristics } \\
\hline VOLUME2 & $2,093.4$ & $2,307.8$ & 49.8 & 94.1 & 749.9 & $3,929.3$ & $5,321.5$ \\
\hline VOLUME5 & $6,669.6$ & $4,948.3$ & 976.6 & $1,623.5$ & $6,579.2$ & $10,390.4$ & $13,664.0$ \\
\hline VOLUME10 & $12,976.1$ & $9,521.9$ & $1,758.6$ & $3,181.2$ & $13,183.1$ & $20,872.4$ & $25,542.2$ \\
\hline VOLUME30 & $6,497.3$ & $2,068.0$ & $4,038.1$ & $5,005.2$ & $6,255.2$ & $7,487.9$ & $9,118.7$ \\
\hline \multicolumn{8}{|c|}{ Excess Returns } \\
\hline XVWRETD & 0.650 & 4.575 & -5.452 & -2.012 & 1.468 & 3.622 & 5.928 \\
\hline XSP500 & 0.478 & 4.396 & -5.688 & -2.000 & 0.949 & 3.361 & 5.535 \\
\hline XAAA & 0.276 & 1.472 & -1.349 & -0.510 & 0.336 & 1.112 & 1.911 \\
\hline XBBB & 0.377 & 1.701 & -1.382 & -0.611 & 0.497 & 1.245 & 2.381 \\
\hline $\mathrm{XCCC}$ & 0.529 & 4.173 & -3.916 & -0.961 & 0.748 & 2.346 & 3.781 \\
\hline XB2 & 0.109 & 0.489 & -0.448 & -0.152 & 0.087 & 0.334 & 0.734 \\
\hline XB5 & 0.232 & 1.245 & -1.506 & -0.554 & 0.279 & 0.914 & 1.816 \\
\hline XB10 & 0.308 & 2.045 & -2.168 & -0.917 & 0.308 & 1.571 & 2.914 \\
\hline XB30 & 0.459 & 3.782 & -3.834 & -1.906 & 0.601 & 2.407 & 4.347 \\
\hline \multicolumn{8}{|c|}{ Macroeconomic Variables } \\
\hline GGDP & 0.601 & 0.654 & -0.284 & 0.342 & 0.674 & 0.966 & 1.273 \\
\hline GCONS & 0.683 & 0.521 & 0.168 & 0.435 & 0.668 & 1.020 & 1.468 \\
\hline MP & 0.504 & 1.482 & -1.376 & 0.171 & 0.757 & 1.182 & 2.114 \\
\hline GUNEMP & 0.227 & 5.489 & -5.051 & -3.636 & -1.152 & 3.333 & 6.383 \\
\hline DEF & 0.993 & 0.465 & 0.620 & 0.700 & 0.875 & 1.110 & 1.410 \\
\hline TERM & 1.695 & 1.195 & 0.040 & 0.670 & 1.650 & 2.810 & 3.350 \\
\hline $\mathrm{TB}$ & 2.768 & 2.251 & 0.060 & 0.160 & 2.595 & 5.090 & 5.440 \\
\hline DY & 0.484 & 0.120 & 0.329 & 0.411 & 0.488 & 0.561 & 0.649 \\
\hline
\end{tabular}




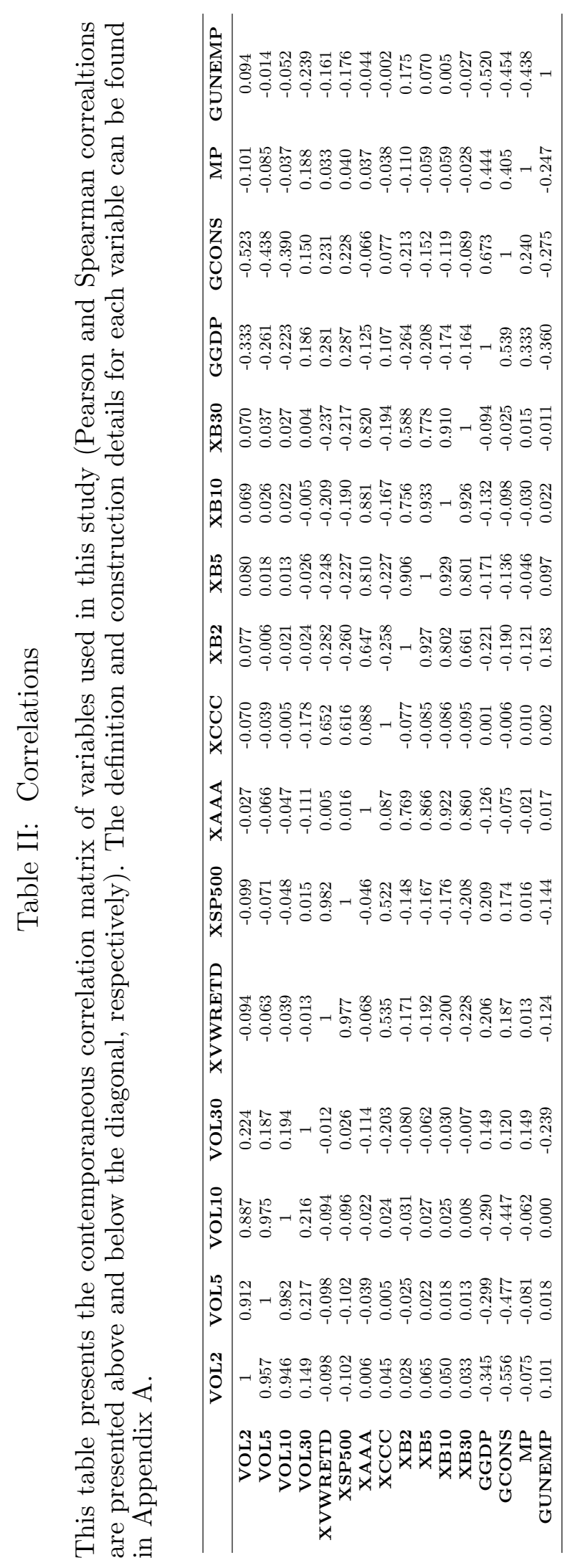




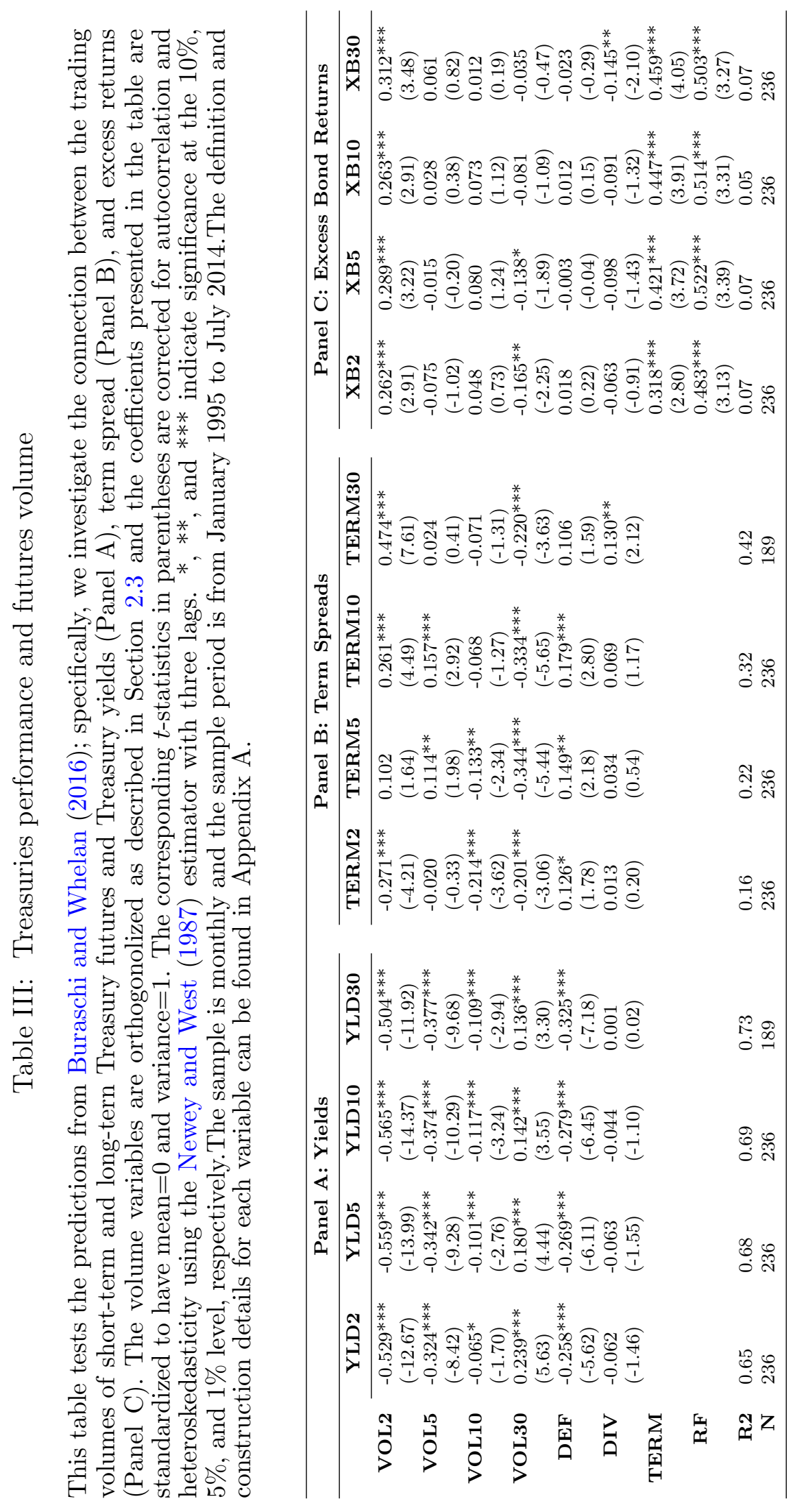


Table IV: Treasury futures volume and financial markets activity

This table presents time-series loadings from regressions of future financial markets activity indicators on treasury futures volumes with different maturities. The model specification takes the following form:

$$
y_{t+1}=\mathbf{V}_{\mathbf{t}} \beta^{V}+\mathbf{C}_{\mathbf{t}} \beta^{C}+\epsilon_{t+1},
$$

where $y_{t+1}$ is the lead financial markets indicator - for equity markets, we consider the complete value-weighted market returns and the SP500 index returns; for credit markets, we consider the $\mathrm{AAA}, \mathrm{BBB}$ and $\mathrm{CCC}$ bond returns calculated based on the BofA Merril Lynch Index. The left hand side returns are in excess of the risk free rate. The volume variables included in matrix $\mathbf{V}$ are 2-, 5-, 10-, and 30-year futures trading volume and the control variables included in matrix $\mathbf{C}$ are default spread, term spread, the risk free rate and the dividend yield (DEF, TERM, RF and DIV, respectively). The volume variables are orthogonolized as described in Section 2.3 and the coefficients presented in the table are standardized to have mean $=0$ and variance $=1$. The corresponding $t$-statistics in parentheses are corrected for autocorrelation and heteroskedasticity using the Newey and West (1987) estimator with three lags. *, **, and *** indicate significance at the $10 \%, 5 \%$, and $1 \%$ level, respectively. The sample is monthly and the sample period is from January 1995 to July 2014. Variable definitions can be found in Appendix A.

\begin{tabular}{rlllll}
\hline & XVWRETD & XSP500 & XAAA & XBBB & XCCC \\
\hline VOL2 & $-0.269^{* * *}$ & $-0.271^{* * *}$ & 0.160 & -0.152 & $-0.320^{* *}$ \\
& $(-2.69)$ & $(-2.86)$ & $(1.60)$ & $(-1.16)$ & $(-2.42)$ \\
VOL5 & -0.004 & -0.015 & 0.036 & -0.026 & -0.001 \\
& $(-0.06)$ & $(-0.25)$ & $(0.57)$ & $(-0.46)$ & $(-0.01)$ \\
VOL10 & 0.126 & 0.115 & 0.128 & 0.196 & 0.178 \\
& $(1.36)$ & $(1.32)$ & $(1.61)$ & $(1.51)$ & $(1.37)$ \\
VOL30 & $0.160^{* *}$ & $0.188^{* * *}$ & -0.098 & -0.084 & 0.012 \\
& $(2.45)$ & $(3.11)$ & $(-1.32)$ & $(-1.28)$ & $(0.21)$ \\
DEF & -0.065 & -0.092 & 0.023 & 0.152 & 0.091 \\
& $(-0.54)$ & $(-0.76)$ & $(0.19)$ & $(1.56)$ & $(0.57)$ \\
TERM & -0.065 & -0.084 & $0.459^{* * *}$ & $0.213^{*}$ & -0.002 \\
& $(-0.56)$ & $(-0.73)$ & $(3.49)$ & $(1.84)$ & $(-0.01)$ \\
RF & $-0.259^{*}$ & $-0.289^{* *}$ & $0.478^{* * *}$ & 0.080 & -0.231 \\
& $(-1.83)$ & $(-2.05)$ & $(2.83)$ & $(0.51)$ & $(-1.44)$ \\
DIV & $0.190^{* * *}$ & $0.190^{* * *}$ & -0.063 & $0.101^{*}$ & $0.273^{* * *}$ \\
& $(2.99)$ & $(3.06)$ & $(-1.15)$ & $(1.93)$ & $(3.30)$ \\
R2 & 0.065 & 0.074 & 0.050 & 0.099 & 0.146 \\
$\mathbf{N}$ & 236 & 236 & 236 & 236 & 236 \\
\hline
\end{tabular}


Table V: Treasury futures volume and economic activity

This table presents time-series loadings from quarterly level regressions of future macroeconomic indicators on treasury futures volumes with different maturities. The model specification takes the following form:

$$
y_{t+1}=\mathbf{V}_{\mathbf{t}} \beta^{V}+\mathbf{C}_{\mathbf{t}} \beta^{C}+\epsilon_{t+1},
$$

where $y_{t+1}$ is the lead macroeconomic indicator (we consider the growth in GDP, consumption, industrial production and unemployment, respectively). The volume variables included in matrix V are 2-, 5-, 10-, and 30-year futures trading volume and the control variables included in matrix C are default spread, term spread, the risk free rate and the dividend yield (DEF, TERM, RF and DIV, respectively). The volume variables are orthogonolized as described in Section 2.3 and the coefficients presented in the table are standardized. The corresponding $t$-statistics in parentheses are corrected for autocorrelation and heteroskedasticity using the Newey and West (1987) estimator with three lags. *,**, and $* * *$ indicate significance at the $10 \%, 5 \%$, and $1 \%$ level, respectively. The sample is quarterly and it covers the period from 1995:Q1 to 2014:Q2. Variable definitions can be found in Appendix A.

\begin{tabular}{rllll}
\hline & GGDP & GCONS & GINDPRO & GUNEMP \\
\hline VOL2 & $-0.482^{* * *}$ & $-0.696^{* * *}$ & $-0.368^{* * *}$ & 0.167 \\
& $(-3.83)$ & $(-6.63)$ & $(-2.95)$ & $(1.40)$ \\
VOL5 & -0.027 & $-0.131^{*}$ & -0.123 & -0.103 \\
& $(-0.33)$ & $(-1.69)$ & $(-1.22)$ & $(-1.09)$ \\
VOL10 & $0.237^{* *}$ & $0.215^{* *}$ & $0.330^{* *}$ & $-0.206^{* *}$ \\
& $(2.12)$ & $(2.43)$ & $(2.22)$ & $(-2.02)$ \\
VOL30 & $0.388^{* * *}$ & $0.212^{*}$ & $0.229^{* * *}$ & $-0.257^{* *}$ \\
& $(4.42)$ & $(1.91)$ & $(2.78)$ & $(-2.49)$ \\
DEF & $-0.308^{* * *}$ & $-0.366^{* * *}$ & $-0.368^{* *}$ & $0.541^{* * *}$ \\
& $(-2.69)$ & $(-4.11)$ & $(-2.35)$ & $(4.73)$ \\
TERM & 0.127 & -0.039 & 0.165 & -0.028 \\
& $(0.89)$ & $(-0.31)$ & $(1.09)$ & $(-0.19)$ \\
RF & -0.318 & $-0.385^{* *}$ & -0.257 & 0.344 \\
& $(-1.58)$ & $(-2.36)$ & $(-1.35)$ & $(1.47)$ \\
DIV & -0.028 & -0.011 & $0.183^{*}$ & -0.074 \\
& $(-0.29)$ & $(-0.13)$ & $(1.98)$ & $(-0.75)$ \\
R2 & 0.392 & 0.534 & 0.303 & 0.389 \\
$\mathbf{N}$ & 78 & 78 & 78 & 78 \\
\hline
\end{tabular}


Table VI: Principal component analysis

Principal components are extracted from the four volume series. Panel A presents the eigenvalues and proportion of variation explained by each of the four principal components (PC1 through PC4, respectively). PC1 should have the highest overall variance. The second component (PC2) has highest variance among all linear combinations that are uncorrelated with PC1 (see Jolliffe (2002) and Jackson (2005) for more details). Panel B presents the correlation between the original trading volume variables and the four principal components. The sample period is from January 1995 to July 2014. Variable definitions can be found in Appendix A.

\begin{tabular}{rrrrr}
\hline \multicolumn{1}{l}{ Panel A: Eigenvalues } \\
\hline Component & Eigenvalue & Difference & Proportion & Cumulative \\
PC1 & 2.915 & 1.978 & 0.729 & 0.729 \\
PC2 & 0.936 & 0.810 & 0.234 & 0.963 \\
PC3 & 0.126 & 0.104 & 0.032 & 0.994 \\
PC4 & 0.023 & \multicolumn{4}{c}{0.006} & 1.000 \\
\hline Panel B: Correlation between PCs and & Trading Volumes \\
\hline VOL2 & PC1 & PC2 & PC3 & PC4 \\
VOL5 & 0.954 & -0.070 & -0.294 & 0.018 \\
VOL10 & 0.981 & -0.123 & 0.101 & -0.114 \\
VOL30 & 0.973 & -0.114 & 0.173 & 0.097 \\
\hline
\end{tabular}




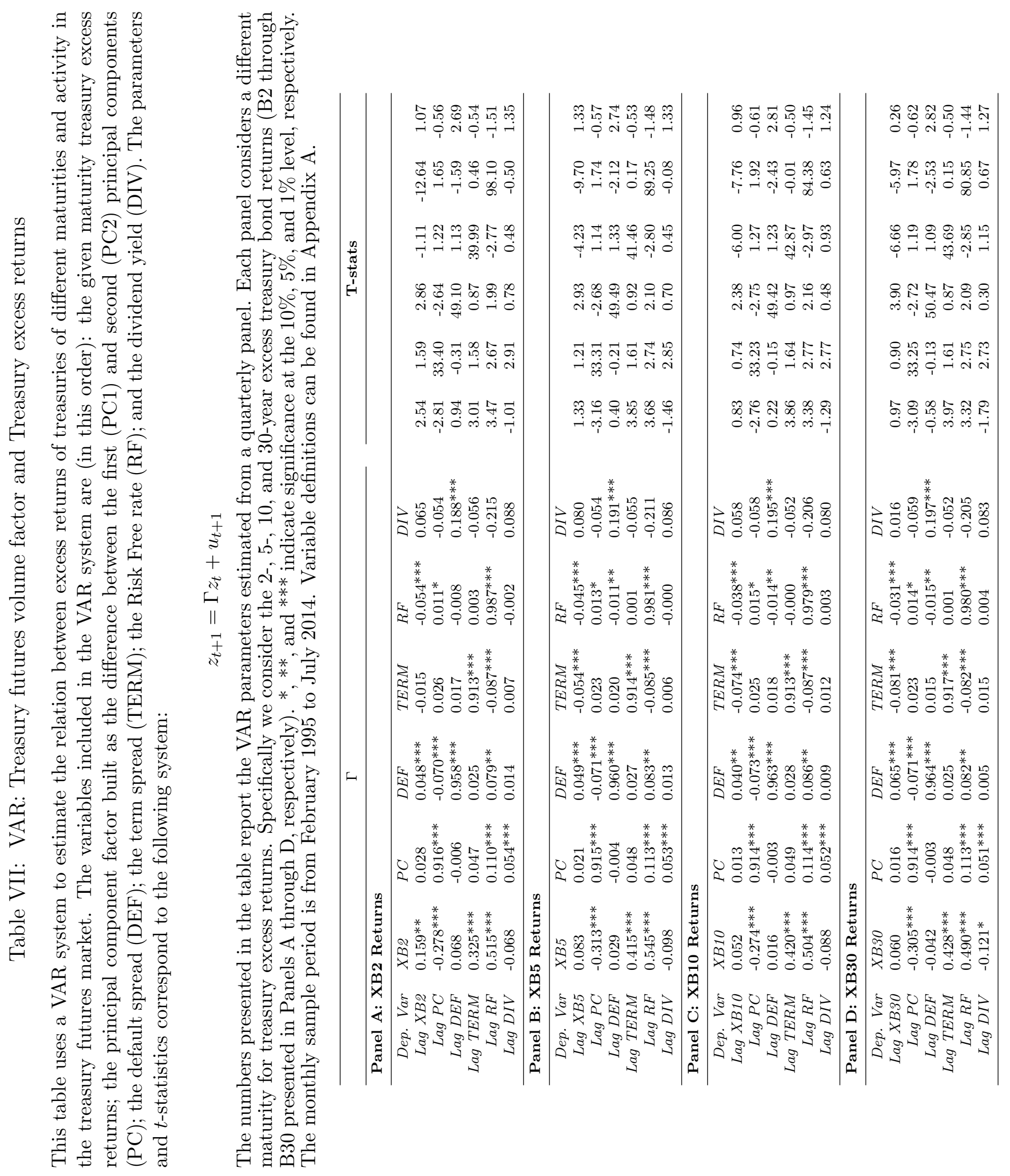




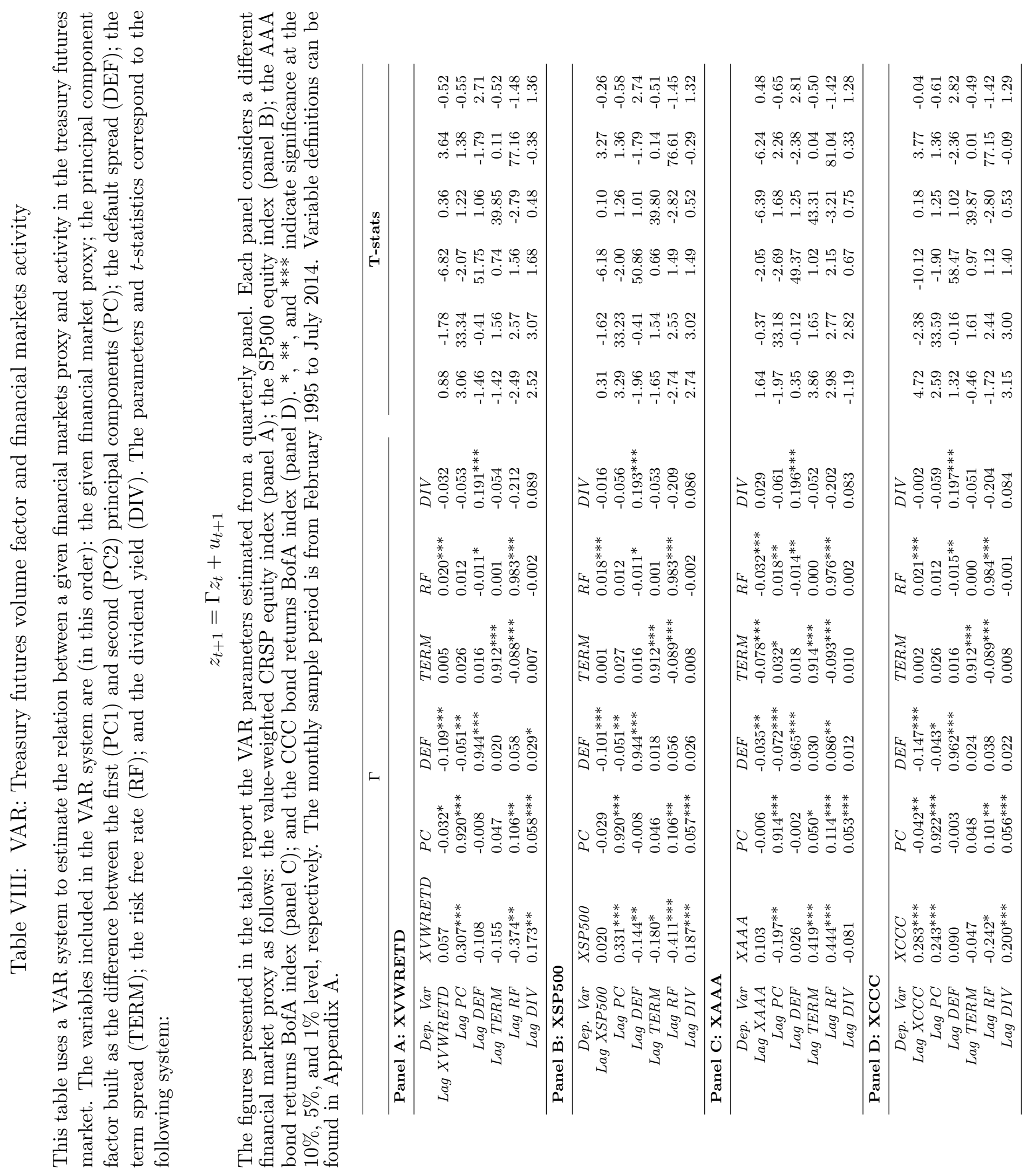




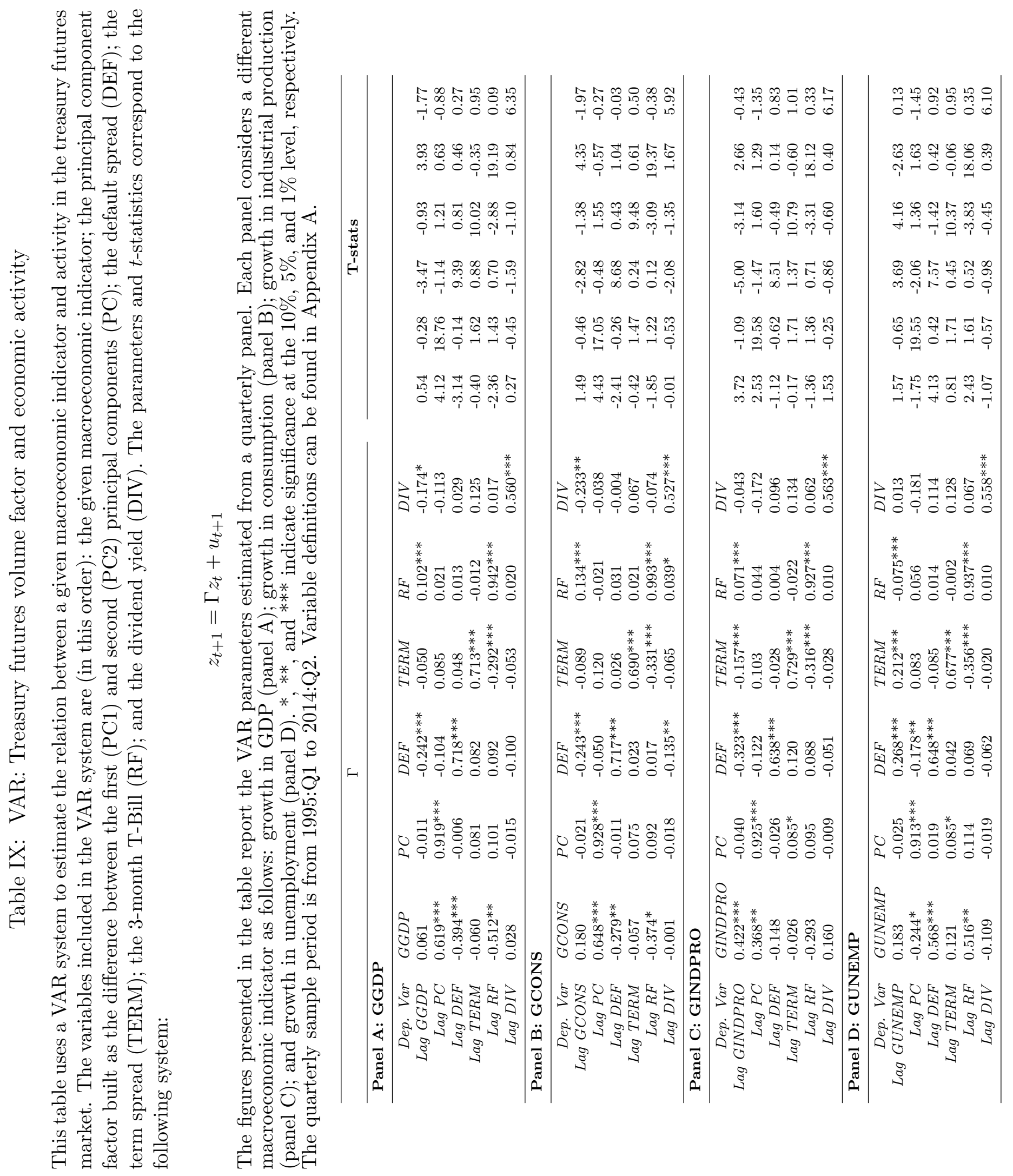


Table X: Long-term forecast

This table presents time-series beta loadings from time series regressions of future financial markets activity (monthly level) and macroeconomic variables (quarterly level) on the principal component futures volume factor (PC). The model specification takes the following form:

$$
y_{t+\tau}=\beta_{0}+\beta_{1} P C_{t}+\beta^{C} \mathbf{C}_{\mathbf{t}}+\epsilon_{t+1}
$$

where $y_{t+\tau}$ is the lead financial markets or macroeconomic variable. $\tau$ represents the lead of the macroeconomic/financial variable (i.e. the number of months ahead for financial markets variables and the number of quarters ahead for macroeconomic variables) and it equals to $1,2,3,4,5,6,9$ and 12. In each panel we report the standardized coefficient estimate on the principal component factor $\left(\beta_{1}\right)$. The control variables included in matrix $\mathbf{C}$ are default spread, term spread, the risk-free rate, and dividend yield (DEF, TERM, TB and DIV, respectively). The corresponding $t$-statistics in parentheses are corrected for autocorrelation and heteroskedasticity using the Newey and West (1987) estimator with three lags. *, **, and *** indicate significance at the $10 \%, 5 \%$, and $1 \%$ level, respectively. The sample covers the period from January 1995 to July 2014. Variable definitions can be found in Appendix A.

\begin{tabular}{|c|c|c|c|c|c|c|c|c|}
\hline Dep. Var. & $\tau=1$ & $\tau=\mathbf{2}$ & $\tau=\mathbf{3}$ & $\tau=4$ & $\tau=5$ & $\tau=6$ & $\tau=\mathbf{9}$ & $\tau=12$ \\
\hline XB2 & $\begin{array}{l}-0.294^{* *} \\
(-2.43)\end{array}$ & $\begin{array}{l}-0.239 * \\
(-1.86)\end{array}$ & $\begin{array}{l}-0.292^{* *} \\
(-2.07)\end{array}$ & $\begin{array}{l}-0.270^{* *} \\
(-2.21)\end{array}$ & $\begin{array}{l}-0.225 \\
(-1.47)\end{array}$ & $\begin{array}{l}-0.153 \\
(-1.09)\end{array}$ & $\begin{array}{l}-0.158 \\
(-1.12)\end{array}$ & $\begin{array}{l}-0.289 * * \\
(-2.49)\end{array}$ \\
\hline XB5 & $\begin{array}{l}-0.318^{* * *} \\
(-3.05)\end{array}$ & $\begin{array}{l}-0.294^{* * *} \\
(-2.61)\end{array}$ & $\begin{array}{l}-0.289^{* * *} \\
(-2.60)\end{array}$ & $\begin{array}{l}-0.291 * * * \\
(-2.87)\end{array}$ & $\begin{array}{l}-0.258^{* *} \\
(-2.09)\end{array}$ & $\begin{array}{l}-0.144 \\
(-1.24)\end{array}$ & $\begin{array}{l}-0.102 \\
(-0.86)\end{array}$ & $\begin{array}{l}-0.239^{* *} \\
(-2.24)\end{array}$ \\
\hline XB10 & $\begin{array}{l}-0.274^{* * *} \\
(-2.74)\end{array}$ & $\begin{array}{l}-0.266^{* *} \\
(-2.54)\end{array}$ & $\begin{array}{l}-0.246^{* *} \\
(-2.55)\end{array}$ & $\begin{array}{l}-0.242^{* * *} \\
(-2.68)\end{array}$ & $\begin{array}{l}-0.236^{* *} \\
(-2.18)\end{array}$ & $\begin{array}{l}-0.136 \\
(-1.33)\end{array}$ & $\begin{array}{l}-0.117 \\
(-1.22)\end{array}$ & $\begin{array}{l}-0.213^{* *} \\
(-2.34)\end{array}$ \\
\hline XB30 & $\begin{array}{l}-0.306^{* * *} \\
(-3.11)\end{array}$ & $\begin{array}{l}-0.282^{* *} \\
(-2.46)\end{array}$ & $\begin{array}{l}-0.274^{* * * *} \\
(-2.67)\end{array}$ & $\begin{array}{l}-0.232^{* *} \\
(-2.34)\end{array}$ & $\begin{array}{l}-0.216^{*} \\
(-1.84)\end{array}$ & $\begin{array}{l}-0.118 \\
(-1.02)\end{array}$ & $\begin{array}{l}-0.081 \\
(-0.79)\end{array}$ & $\begin{array}{l}-0.159 \\
(-1.46)\end{array}$ \\
\hline XVWRETD & $\begin{array}{l}0.324^{* * *} \\
(2.85)\end{array}$ & $\begin{array}{l}0.333^{* * *} \\
(2.93)\end{array}$ & $\begin{array}{l}0.397 * * * \\
(3.49)\end{array}$ & $\begin{array}{l}0.370^{* * *} \\
(2.85)\end{array}$ & $\begin{array}{l}0.284^{* *} \\
(2.31)\end{array}$ & $\begin{array}{l}0.240^{* *} \\
(2.11)\end{array}$ & $\begin{array}{l}0.189 \\
(1.54)\end{array}$ & $\begin{array}{l}0.196 \\
(1.56)\end{array}$ \\
\hline XSP500 & $\begin{array}{l}0.340^{* * *} \\
(3.18)\end{array}$ & $\begin{array}{l}0.346^{* * *} \\
(3.26)\end{array}$ & $\begin{array}{l}0.408^{* * *} \\
(3.72)\end{array}$ & $\begin{array}{l}0.380 * * * \\
(3.06)\end{array}$ & $\begin{array}{l}0.298^{* *} \\
(2.47)\end{array}$ & $\begin{array}{l}0.262^{* *} \\
(2.37)\end{array}$ & $\begin{array}{l}0.203^{*} \\
(1.72)\end{array}$ & $\begin{array}{l}0.218^{*} \\
(1.80)\end{array}$ \\
\hline XAAA & $\begin{array}{l}-0.187 \\
(-1.58)\end{array}$ & $\begin{array}{l}-0.155 \\
(-1.29)\end{array}$ & $\begin{array}{l}-0.121 \\
(-1.05)\end{array}$ & $\begin{array}{l}-0.102 \\
(-0.98)\end{array}$ & $\begin{array}{l}-0.093 \\
(-0.83)\end{array}$ & $\begin{array}{l}-0.032 \\
(-0.30)\end{array}$ & $\begin{array}{l}-0.055 \\
(-0.56)\end{array}$ & $\begin{array}{l}-0.144 \\
(-1.49)\end{array}$ \\
\hline $\mathrm{XCCC}$ & $\begin{array}{l}0.308^{* *} \\
(2.01)\end{array}$ & $\begin{array}{l}0.302^{* *} \\
(2.02)\end{array}$ & $\begin{array}{l}0.358^{* *} \\
(2.49)\end{array}$ & $\begin{array}{l}0.363^{* *} \\
(2.31)\end{array}$ & $\begin{array}{l}0.308^{* *} \\
(2.21)\end{array}$ & $\begin{array}{l}0.172 \\
(1.33)\end{array}$ & $\begin{array}{l}0.022 \\
(0.14)\end{array}$ & $\begin{array}{l}-0.010 \\
(-0.06)\end{array}$ \\
\hline GGDP & $\begin{array}{l}0.638^{* * *} \\
(3.28)\end{array}$ & $\begin{array}{l}0.749^{* * *} \\
(3.54)\end{array}$ & $\begin{array}{l}0.812^{* * *} \\
(4.11)\end{array}$ & $\begin{array}{l}0.856^{* * * *} \\
(4.36)\end{array}$ & $\begin{array}{l}0.849^{* * *} \\
(4.04)\end{array}$ & $\begin{array}{l}0.762^{* * * *} \\
(4.22)\end{array}$ & $\begin{array}{l}0.287 \\
(1.14)\end{array}$ & $\begin{array}{l}0.034 \\
(0.20)\end{array}$ \\
\hline GCONS & $\begin{array}{l}0.763^{* * *} \\
(4.00)\end{array}$ & $\begin{array}{l}0.905^{* * *} \\
(5.20)\end{array}$ & $\begin{array}{l}0.988^{* * *} \\
(5.71)\end{array}$ & $\begin{array}{l}1.022^{* * *} \\
(5.99)\end{array}$ & $\begin{array}{l}1.069^{* * *} \\
(7.61)\end{array}$ & $\begin{array}{l}1.027^{* * *} \\
(7.79)\end{array}$ & $\begin{array}{l}0.660^{* *} \\
(2.61)\end{array}$ & $\begin{array}{l}0.307 \\
(1.63)\end{array}$ \\
\hline GINDPRO & $\begin{array}{l}0.475^{* *} \\
(2.08)\end{array}$ & $\begin{array}{l}0.677^{* *} \\
(2.36)\end{array}$ & $\begin{array}{l}0.785^{* * *} \\
(2.73)\end{array}$ & $\begin{array}{l}0.788^{* *} \\
(2.63)\end{array}$ & $\begin{array}{l}0.663^{* *} \\
(2.56)\end{array}$ & $\begin{array}{l}0.549^{*} \\
(1.96)\end{array}$ & $\begin{array}{l}0.010 \\
(0.03)\end{array}$ & $\begin{array}{l}-0.124 \\
(-0.57)\end{array}$ \\
\hline GUNEMP & $\begin{array}{l}-0.272^{*} \\
(-1.74)\end{array}$ & $\begin{array}{l}-0.454^{* *} \\
(-2.09)\end{array}$ & $\begin{array}{l}-0.586^{* *} \\
(-2.32)\end{array}$ & $\begin{array}{l}-0.781 * * * \\
(-3.54)\end{array}$ & $\begin{array}{l}-0.816^{* * *} \\
(-3.92)\end{array}$ & $\begin{array}{l}-0.744^{* * *} \\
(-3.33)\end{array}$ & $\begin{array}{l}-0.356 \\
(-1.63)\end{array}$ & $\begin{array}{l}0.095 \\
(0.40)\end{array}$ \\
\hline
\end{tabular}




\section{Appendix A. Variable Definitions}

The table below explains the construction of variables used in this study. Return variables are at monthly levels, while macroeconomic variables are at quarterly level. 


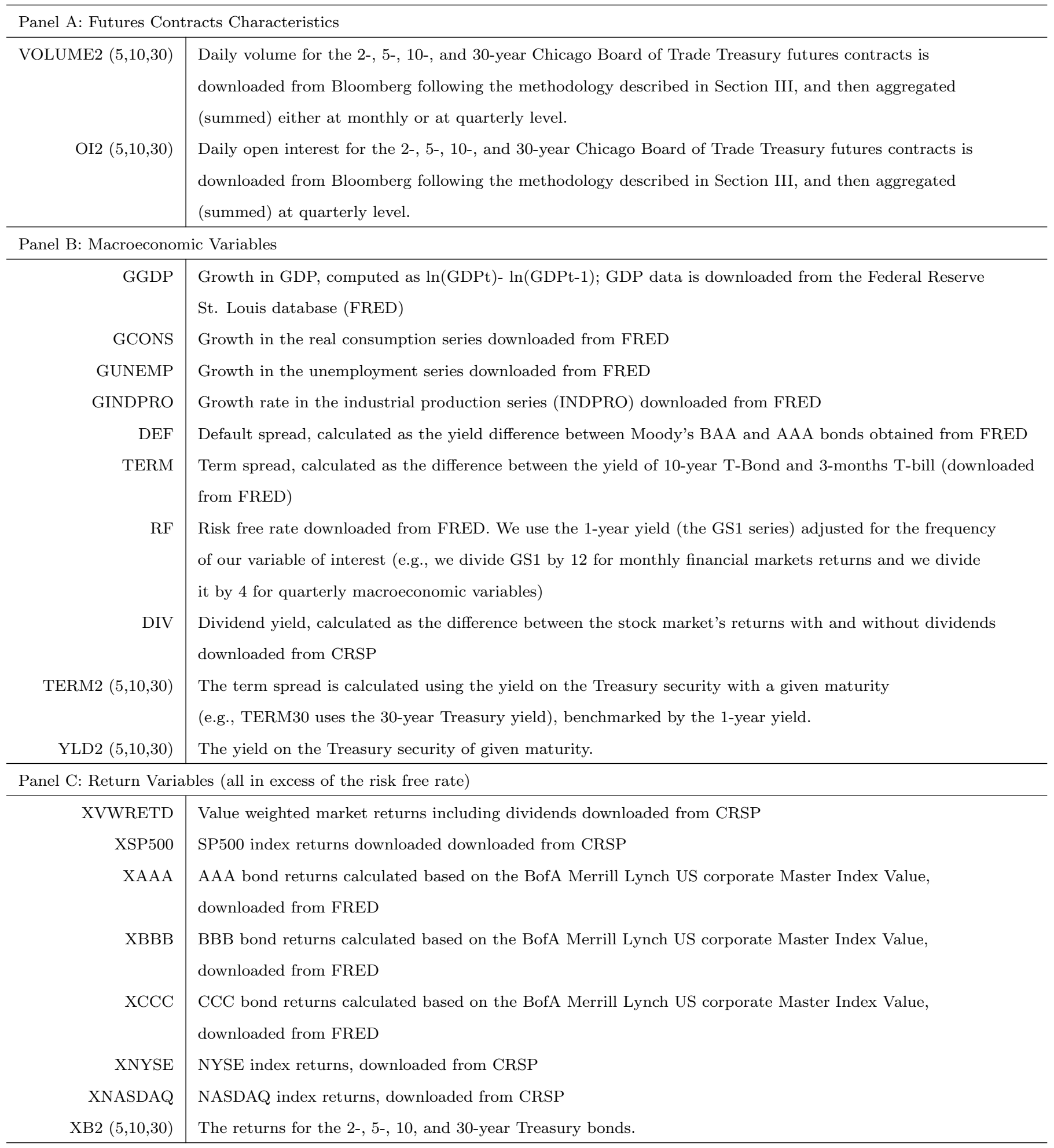

